J. Ginseng Res.

Vol. 29, No. 1, 1-18(2005)

\author{
홍삼과 백삼의 비교 고찰 \\ 남 기 열\# \\ 한국과학기술정보연구원 \\ (2005년 1월 17일 접수, 2005년 2월 28일 수리)
}

\title{
The Comparative Understanding between Red Ginseng and White Ginsengs Processed Ginsengs (Panax ginseng C. A. Meyer)
}

\author{
Ki-Yeul Nam ${ }^{\#}$ \\ Korea Institute of Science and Technology Information, 52 Eoeun-dong Yusung Gu,Taejeon, 305-806, Korea \\ (Received January 17, 2005, Accepted February 28, 2005)
}

\begin{abstract}
Ginseng Radix, the root of Panax ginseng C. A. Meyer has been used in Eastern Asia for 2000 years as a tonic and restorative, promoting health and longevity. Two varieties are commercially available: white ginseng(Ginseng Radix Alba) is produced by air-drying the root, while red ginseng(Ginseng Radix Rubra) is produced by steaming the root followed by drying. These two varieties of different processing have somewhat differences by heat processing between them. During the heat processing for preparing red ginseng, it has been found to exhibit inactivation of catabolic enzymes, thereby preventing deterioration of ginseng quality and the increased antioxidant-like substances which inhibit lipid peroxide formation, and also good gastro-intestinal absorption by gelatinization of starch. Moreover, studies of changes in ginsenosides composition due to different processing of ginseng roots have been undertaken. The results obtained showed that red ginseng differ from white ginseng due to the lack of acidic malonyl-ginsenosides. The heating procedure in red ginseng was proved to degrade the thermally unstable malonyl-ginsenoside into corresponding netural ginsenosides. Also the steaming process of red ginseng causes degradation or transformation of neutral ginsenosides. Ginsenosides $R_{2}, R_{4}$, $\mathrm{Rs}_{3}, \mathrm{Rs}_{4}$ and $\mathrm{Rg}_{5}$, found only in red ginseng, have been known to be hydrolyzed products derived from original saponin by heat processing, responsible for inhibitory effects on the growth of cancer cells through the induction of apoptosis. $20(\mathrm{~S})$-ginsenoside $\mathrm{Rg}_{3}$ was also formed in red ginseng and was shown to exhibit vasorelaxation properties, antimetastatic activities, and anti-platelet aggregation activity. Recently, steamed red ginseng at high temperature was shown to provide enhance the yield of ginsenosides $\mathrm{Rg}_{3}$ and $\mathrm{Rg}_{5}$ characteristic of red ginseng Additionally, one of non-saponin constituents, panaxytriol, was found to be structually transformed from polyacetylenic alcohol(panaxydol) showing cytotoxicity during the preparation of red ginseng and also maltol, antioxidant maillard product, from maltose and arginyl-fructosyl-glucose, amino acid derivative, from arginine and maltose. In regard to the in vitro and in vivo comparative biological activities, red ginseng was reported to show more potent activities on the antioxidant effect, anticarcinogenic effect and ameliorative effect on blood circulation than those of white ginseng. In oriental medicine, the ability of red ginseng to supplement the vacancy(虛) was known to be relatively stronger than that of white ginseng, but very few are known on its comparative clinical studies. Further investigation on the preclinical and clinical experiments are needed to show the differences of indications and efficacies between red and white ginsengs on the basis of oriental medicines.
\end{abstract}

Key words : Panax ginseng, red ginseng, white ginseng, ginsenosides, heat processing

\#본 논문에 관한 문의는 이 저자에게로

(전화) 042-869-0685; (팩스) 042-869-0679

(E-mail) insam704@naver.com 


\section{서 론}

인삼은 Panax ginseng C. A. Meyer를 기원 식물로 한 건 조 근을 말하며, 가공방법에 따라 크게 홍삼과 백삼으로 분류 된다. 홍삼은 생인삼(수삼)을 수증기 또는 기타 방법으로 쪄서 익혀 건조한 것을 말하며, 백삼은 수삼을 햇볕 - 열풍 또는 기 타 방법으로 익히지 아니하고 말린 것을 말한다.

우리나라의 홍삼 제조 역사는 고려도경(1123년 중국 宋代 의 徐兢이 著述)에 생삼(生蓼)과 오늘날의 홍삼에 해당되는 “숙삼(熟落: 찐삼)”에 대한 문헌적 기록이 있는 것으로 보아 오래 전에 홍삼이 제조된 것으로 보여 진다. 아마도 당시 중 국 등에 수출할 때 인삼의 부패를 방지하거나 장기보존을 위 한 목적에서 제조된 것으로 여겨진다. "홍삼"이란 문자가 처 음 기록된 것은 「정조실록」에서 찾아볼 수 있고, 법령에 사 용된 것은 고종 20년(1883년) 조선국세관규칙에서 비롯되었 다. 그러나 홍삼이 국가 차원에서 본격적으로 제조된 것은 1908 년(융희 2년) 홍삼전매법이 제정 공포된 이후부터이다. 그 동안 약 100 여 년에 걸쳐 홍삼은 백삼과는 다르게 홍삼 전매법에 의해 국가가 그 제조 독점권을 가지고 있었으나, 새 로운 인삼산업법의 제정과 홍삼전매법의 폐지로 1996년 7월 1 일부터는 민간기업에서도 일정한 시설기준을 갖추면 제조할 수 있게 되었다.

우리나라를 비롯한 일본과 중국의 약전에는 백삼(Ginseng Radix Alba)과 홍삼(Ginseng Radix Rubra)이 별도로 수재 되어있다. 이는 기원식물은 같지만 제조가공 방법에 차이가 있 어 어느 정도 서로 다른 특성을 가지고 있음을 암시해 준다.

그러나 인삼은 전통약물로서 그 효능은 한방의학에 뿌리를 두고 있고, 한방 의서에 기록된 인삼이 대부분 백삼이었다는 점에서 가공방법에 따라 구분되는 두 종류의 인삼 간에 과연 어떤 차이가 있는지에 대해 많은 관심이 모아졌다. 홍삼과 백 삼의 차이에 대한 과학적 연구는 1980 년도 초부터 일본의 Kitagawa 연구팀에 의해 주요 전승약물의 가공법인 수치(修治 : processing)방법에 대한 과학적 해명연구의 일환으로 인삼의 수치법의 차이에 기인한 함유성분의 변화 등에 관한 연구를 시작으로 본격화되었다. ${ }^{1-3)}$ 이를 계기로 인삼의 가공방법에 따 라 분류되는 홍삼과 백삼의 성분과 약리활성에 대한 과학적 연구결과들이 속속 발표되었다. 이러한 일련의 실험적 연구를 통해 홍삼이 백삼에 비해 비교 우위적 차별성이 밝혀지고 있 으나, 임상적용 시험을 통한 그 효과의 차별성에 대한 비교 평가는 아직 미흡한 실정이다.

또한 홍삼은 전술한 바와 같이 우리나라에서 오랜 제조역 사를 가지고 있으나 전매품으로서 해외로 거의 전량이 수출 되어 실제 국내에서 시판은 1986년 이 후부터로 그 동안 일
반적 국내 소비는 백삼에 비해 적었고 정보도 매우 제한적이 었다.

따라서 본 논문에서는 인삼의 가공방법에 따라 구분되는 홍 삼과 백삼 간에 이화학적 특성을 비롯하여 그 성분과 약리효 능 등에 어먼 차별성이 있는지에 대한 이해를 돕고자 지금까 지의 연구결과들을 종합하고 검토·고찰하였다.

\section{이화학적 톡성 비교}

\section{1. 홍삼과 백삼의 전분 특성}

인삼 근은 약 $30 \%$ 의 전분을 함유하고 있고, 그 전분 입자 의 형태는 구형(rounded) 또는 다각형(polygonal)이고, 크기는 직경 2.0-7.5 $\mu$ 의 범위이다. ${ }^{4)}$ 홍삼은 증숙할 때 열처리가 가 해지므로 인삼의 전분이 호화(糊化)되고 아미노-카보닐 반응 (amino-carbonyl reaction)에 의해 내용조직은 담황갈색 적갈 색을 띄게 된다. 인삼전분은 $50^{\circ} \mathrm{C}$ 에서는 약간 팽윤되기 시작 하여 $55 \sim 60^{\circ} \mathrm{C}$ 에서 최대를 이루어 미셀(micelles)구조가 파괴 되고 인삼전분입자의 결정성이 점차 상실되어 $65-70^{\circ} \mathrm{C}$ 에서는 호화전분이 겔(gel)상태를 이룬다. ${ }^{5)}$ 인삼전분의 호화개시온도 는 amylograph를 사용하여 측정한 amylogram에 의하면 $61^{\circ} \mathrm{C}$ 이고, 완전한 호화는 $88^{\circ} \mathrm{C}$ 에서 일어난다. ${ }^{4)}$

일반적으로 호화전분은 생전분의 경우와 달리 이미 아밀로 스나 아밀로펙틴 분자들, 특히 아밀로스 분자들의 미셀이 붕 괴되어 모든 분자들이 분산 또는 풀어져 있는 상태에 있으므 로, 물을 가하여 잠시 가열하거나 뜨거운 물을 가하면 물이 급속하게 흡수되어 팽윤되며, 곧 다시 완전한 호화상태가 된 다. 호화전분 즉 $\alpha$-전분은 그 속의 전분분자들이 모두 완전 히 풀어진 상태이므로 전분분해효소들의 작용을 받기 쉽다. 따라서 호화전분으로 된 식품은 생전분으로 된 식품보다 소 화율(digestibility)이 좋다고 알려져 있다. 인삼의 경우도 생전 분 상태인 백삼보다는 전분이 호화 된 홍삼의 경우 끓일 때 내용 성분이 잘 우러나오고, ${ }^{6)}$ 복용 후 소화흡수도 잘 되는 것으로 여겨진다.

\section{2. 품질안정성}

홍삼은 제조과정 중 특수한 “증숙(蒸熟)" 공정을 거치는 동 안 인삼 조직중의 전분입자가 호화(gelatinization)되어, 조직 이 견고하고, 각종 효소들이 불활성화 되므로 장기 보존 중에 도 뚜렷한 성분 변화가 거의 일어나지 않는다.

최 등 ${ }^{2)}$ 은 진공포장 된 고려홍삼을 $12-28^{\circ} \mathrm{C}$, 상대습도 55 $68 \%$ 의 조건하에서 10여 년간(1977-1986)에 걸쳐 저장기간별 사포닌 성분과 지방산(fatty acids), 지질(lipids), 당(sugars) 등 각종 성분 변화에 대해 조사하였다. 그 결과 저장기간별 
일반 성분을 비롯한 사포닌 및 유리아미노산 함량에 있어 유 의할 만한 변화는 관찰되지 않았다. 특히 불포화도가 높아 산 화되기 쉬운 linoleic $\operatorname{acid}(\mathrm{C} 18: 2)$ 및 linolenic $\operatorname{acid}(\mathrm{C} 18$ : 3 )도 매우 안정하였다. 한편 저장기간이 길어질수록 갈색도가 증가되고, 산도 $(\mathrm{pH})$ 는 약간 저하하는 경향을 보였다.

Kitagawa 등1)은 동일한 원료수삼으로 홍삼과 백삼을 각각 제조하여 지질성분의 변화를 조사하였다. 그 결과 수삼 중의 복합지질성분인 그리세로-당지질(glycero-galacto-lipid)의 경우, 홍삼에는 존재하지만 백삼에서는 검출되지 않았다. 스테롤배당 체 지방산에스테르(steryl glycoside fatty acid ester)도 수삼과 홍삼에 비해 백삼에서 함량의 감소가 현저하였다. 이는 수삼 중의 estrase 등의 효소가 홍삼 제조 과정 중 열처리에 의해 불활성화 됨으로 수삼중의 복합지질이 홍삼에는 그대로 유지되 지만, 백삼 의 경우는 완만한 건조과정에서 이들 효소가 작용 할 수 있어 그 성분의 분해가 일어나기 때문으로 해석된다.

또한 홍삼은 찐 후 건조과정에서 갈색화반응이 일어나고, 홍 삼의 장기 저장 시에도 비효소적 갈색화 반응이 완만하게 진행 되어 갈색화반응 생성물이 증가되는데, 이때 생기는 갈색화 반 응생성물은 항산화 활성을 나타내며, ${ }^{8)}$ 아울러 인삼에 함유된 지방산의 산패를 억제함으로서 품질 안정성을 양호하게 한다.7

따라서 홍삼은 백삼에 비해 품질안정성이 양호하여 저장기 간이 횔씬 길다. 현재 인삼산업법에서도 진공포장의 경우 검 사유효기간을 홍삼은 10 년 이내로, 백삼은 3 년 이내로 규정하 고 있다.

\section{홍삼과 백삼의 성분 특성과 약리활성}

인삼은 triterpenoid saponins을 비롯하여 polyacetylenes 와 sesquiterpenes를 포함한 정유(essential oils), 페놀 화합 물 (phenolic compounds), 다당체(polysaccharides), 펩티도 그리칸(peptidoglycans)과 비타민 및 알칼로이드를 포함한 함 (속)질소 화합물, 그리고 일반성분으로서 지방산과 탄수화물 등을 함유하고 있다.9) 인삼의 주요 약리활성 성분은 사포닌 성분으로 알려지고 있으나, 인삼 중에는 비사포닌계의 여러 가지 약리활성 성분도 함유하고 있다. 이러한 성분 중 일부
성분들은 홍삼제조과정 중 화학구조가 변환되어 새로운 성분 이 생성되기도 하고 또한 일부 생리활성 성분의 함량 증가도 일어난다. ${ }^{9)}$

\section{1. 사포닌 성분}

1) 사포닌 성분의 조성 특성: 인삼의 주요 유효성분인 인 삼사포닌은 수치법에 의해 함량과 그 조성이 상당히 변화한 다는 것이 밝혀지게 되었고, ${ }^{2,10)}$ 지금까지 홍삼과 백삼으로부 터 분리된 ginsenosides(GS)가 각각 32 종, 24 종이고, 이 중 에는 홍삼과 백삼의 공통 GS가 18 종, 홍삼특유의 GS가 14 종, 백삼 특유의 GS가 6 종이다[Table 1. 참조]. 홍삼 특유의 GS는 증숙과정 (steaming process) 중 열처리(heating)에 의 한 가수분해(hydrolysis) 반응에 의해 생성된다.

백삼 중에는 그 특유의 트리테르펜 올리고 배당체(triterpene-oligoglygoside)인 malonyl-ginsenosides(M-G)들이 발견 되었다. M-G는 protopanaxadiol 계의 $\mathrm{G}-\mathrm{Rb}_{1}, \mathrm{G}-\mathrm{Rb}_{2}, \mathrm{G}-\mathrm{Rc}$, $\mathrm{G}-\mathrm{Rd}$ 의 3 위 당쇄의 말단 glucose 6 의 수산기에 malonyl acid의 carboxyl 기가 ester 결합을 한 산성사포닌의 일종이 다. 이들 M-G는 다른 Ginsenoside(이하 "G"로 표기)와는 다르게 수용성이 매우 강하고, malonyl 기는 불안정하여 물 로 가열하면 쉽게 이탈된다. 따라서 수삼으로부터 홍삼제조과 정 중 탈(脫) malonyl 화(demalonylation)와 함께 비당부 (aglycone)의 C-20 당쇄(glycosyl residue)의 이탈(elimination) 또는 C-20 수산기 입체배위(configuration)의 이성화(isomerazation)가 일어난다. 각 사포닌의 증감 양상과 현재 판명되고 있는 사포닌의 구조로부터 추정해 보면. $\mathrm{M}-\mathrm{G}-\mathrm{Rb}_{1} \rightarrow \mathrm{Quinque}-$ noside- $\mathrm{R}_{1} \rightarrow \mathrm{G}-\mathrm{Rb}_{1} ; \mathrm{M}-\mathrm{G} \quad-\mathrm{Rb}_{2} \rightarrow \mathrm{G}-\mathrm{Rs}_{1} \rightarrow \mathrm{G}-\mathrm{Rb}_{2} ; \mathrm{M}-\mathrm{G}-$ $\mathrm{Rc} \rightarrow \mathrm{G}_{-} \mathrm{Rs}_{2} \rightarrow \mathrm{G}-\mathrm{Rc} ; \mathrm{MI}-\mathrm{G}-\mathrm{Rd} \rightarrow \mathrm{G}-\mathrm{Rd}$ 로 되는 것으로 여겨 지고 있다. ${ }^{1,2,11)} \mathrm{M}-\mathrm{G}$ 의 약리활성에 대해서는 거의 조사되지 않았으며, 다만, M-G-Rb 이 기억학습 기능에 영항을 주는 랫 드 뇌 해마체의 LTP(long-term potentiation)생성을 촉진하는 효과가 있다는 것이 보고되었다. ${ }^{12)}$

2) 사포닌 성분의 함량: 홍삼제조 시 일부 미량 생리활성 성분의 함량 증가가 일어난다는 것이 밝혀졌다. Kitagawa 등 ${ }^{13)}$

Table 1. Comparsion of ginsenoside composition between red ginseng and white ginseng

\begin{tabular}{|c|c|c|}
\hline $\begin{array}{c}\text { Common } \\
\text { ginsenosides (18) }\end{array}$ & $\begin{array}{l}\text { White ginseng's characteristic } \\
\text { ginsenosides (6) }\end{array}$ & $\begin{array}{l}\text { Red ginseng's characteristic } \\
\text { ginsenosides (14) }\end{array}$ \\
\hline $\begin{array}{l}\text { ginsenoside-Ro, }-\mathrm{Ra}_{1},-\mathrm{Ra}_{2} \text {, } \\
-\mathrm{Ra}_{3},-\mathrm{Rb},-\mathrm{Rb}_{2},-\mathrm{Rb}_{3},-\mathrm{Rc}, \\
-\mathrm{Rd},-\mathrm{Re},-\mathrm{Rf},-\mathrm{Rg}_{1},-\mathrm{Rg}_{2} \text {, } \\
-\mathrm{Rg}_{3},-\mathrm{Rh} \mathrm{h}_{1} \\
\text { quinquenoside- } \mathrm{R}_{1} \text {, } \\
\text { notoginsenoside- } \mathrm{R}_{1} \text {, } \\
\text { 20-gluco-ginsenoside- } \mathrm{Rf}\end{array}$ & $\begin{array}{l}\text { malonyl-ginsenoside- } \mathrm{Rb}_{1} \\
\text { malonyl-ginsenoside- } \mathrm{Rb}_{2} \\
\text { malonyl-ginsenoside- } \mathrm{Rc} \\
\text { malonyl-ginsenoside- } \mathrm{Rd} \\
\text { Koryoginsenoside- } \mathrm{R}_{1} \\
\text { Koryoginsenoside- } \mathrm{R}_{2}\end{array}$ & $\begin{array}{l}\text { ginsenoside- } \mathrm{Rh}_{2}, \\
-\mathrm{Rs}_{1},-\mathrm{Rs}_{2},-\mathrm{Rs}_{3},-\mathrm{Rs}_{4}, \\
-\mathrm{Rh}_{4},-\mathrm{Rg}_{5},-\mathrm{Rg}_{6},-\mathrm{F}_{4}, \mathrm{Rf}_{2} \\
20(\mathrm{~S}) \text {-ginsenoside- } \mathrm{Rg}_{3}, \\
\text { 20(R)-ginsenoside- } \mathrm{Rg}_{2}, \\
\text { 20(R)-ginsenoside- } \mathrm{Rh}_{1}, \\
\text { quinoginsenoside- } \mathrm{R}_{4}\end{array}$ \\
\hline
\end{tabular}


은 동일한 원료 수삼으로부터 제조된 홍삼과 백삼의 공통 함유 미량 사포닌들의 함량을 비교한 결과 $\mathrm{G}-\mathrm{Rh}_{1}, \mathrm{G}-\mathrm{Rg}_{2}, \mathrm{G}-\mathrm{Rg}_{3}$ 의 경우 백삼 중 함량이 각각 $0.0015 \%, 0.014 \%, 0.0003 \%$ 인 데 비해 홍삼제조 시는 각각 $0.006 \%, 0.024 \%, 0.014 \%$ 로 백삼보 다 홍삼에서 함량이 높다는 것을 확인하였다. 그러나 이는 절 대적 함량증가가 아닌 ginsenosides의 구조변환에 의해 증가가 일어나는데, 예를 들면 홍삼제조과정 열처리에 의한 가수분해 반응에 의해 $\mathrm{G}-\mathrm{Rb}_{1}$ 등의 $\mathrm{PD}$ 계 사포닌으로부터 $\mathrm{G}-\mathrm{Rg}_{3}$ 로, $\mathrm{G}-$ $\mathrm{Re}$ 는 $\mathrm{G}-\mathrm{Rg}_{2}$ 혹은 $\mathrm{G}-\mathrm{Rh}_{1}$ 로 변환됨으로 실제로는 증감이 일어 난다고 보아야 한다. 이들 성분의 악리활성으로 $\mathrm{G}-\mathrm{Rh}_{1}$ 은 간 장 해억제작용, ${ }^{14)}$ 종양세포(F9 cells)의 분화촉진, ${ }^{15)}$ 혈소판의 응집 억제, ${ }^{16)} \mathrm{G}-\mathrm{Rg}_{2}$ 는 혈소판응집 ${ }^{17)}$ 및 평활근 세포증식의 억제, ${ }^{17)}$ 카테콜아민(CA)분비 억제 및 세포 내 칼습유입억제작용, 19,20 ) 기억력 감퇴 개선 작용 ${ }^{101)}$ 등이 보고되고 있다.

Samukawa 등 ${ }^{21)}$ 은 HPLC-UV 방법을 이용하여 홍삼의 증 숙 과정 중 생성되는 미량 진세노사이드의 분해 산물을 측정 하였다. 그 결과 백삼 중에 원래 존재하는 18 종의 진세노사 이드와 함께 $\mathrm{G}-20(\mathrm{R})-\mathrm{Rg}_{2},-20(\mathrm{R})-\mathrm{Rh}_{1},-20(\mathrm{~S})-\mathrm{Rg}_{3},-20(\mathrm{R})-$ $\mathrm{Rg}_{3}$ 등이 검출되었다(Table 2).

또한 Samukawa 등 ${ }^{21)}$ 의 조사결과(Table 2)에서 보면 증삼
시간 $0.1,2,3$ 시간에 따른 총 진세노사이드 함량은 각각 $35.4,42.1,58.0,50.3 \mathrm{mg} / \mathrm{g}$ 로서 증삼하지 않은(0 time) 인삼에 비해 증삼 2 시간까지 증가하다가 증삼 3 시간 후에는 오히려 함량이 감소되었다. 그러나 $\mathrm{G}-\mathrm{Rg}_{3}$ 를 비롯한 일부 성 분은 증삼 3 시간까지 증가되었다. 이러한 분석결과는 증삼하 지 않은 백삼보다는 증삼한 인삼(홍삼)에서 총 진세노사이드 함량이 증가되는 것으로 보여 지고 있으나, 이는 백삼의 특유 성분인 M-G의 함량은 분석되지 않았기 때문으로 사료된다. 더욱이 이는 Table 3 에서와 같이 증삼 시간이 증가됨에 따라 $\mathrm{M}-\mathrm{G}$ 의 함유율의 갇소가 현저함을 보여 주었는데, 이는 $\mathrm{M}-\mathrm{G}$ 의 타 성분으로의 변환에 의한 감소로 이해된다. 특히 백삼 중 $\mathrm{M}-\mathrm{G}$ 함량 분석결과를 보면 산성사포닌인 $\mathrm{M}-\mathrm{G}-\mathrm{Rb}_{1}$, $-\mathrm{Rb}_{2},-\mathrm{Rc},-\mathrm{Rd}$ 함량이 각각 $0.82,0.41,0.30,0.12 \%$ 로서 중성사포닌인 $\mathrm{G}-\mathrm{Rb}_{1} 0.47, \mathrm{G}-\mathrm{Rb}_{2} 0.21, \mathrm{G}-\mathrm{Rc} 0.26, \mathrm{G}-\mathrm{Rd}$ $0.15 \%$ 와 비교 시 백삼 중에는 $\mathrm{M}-\mathrm{G}$ 의 총 함량이 오히려 많 은 것으로 보고되었다. ${ }^{22)}$

한편 홍삼은 관행적으로 $98^{\circ} \mathrm{C}$ 내외에서 2 시간정도 찐 후 건 조하여 제조한다. 그러나, $120^{\circ} \mathrm{C}$ 의 고온에서 3 시간 증삼하면 보다 극성이 적은 진세노사이드로서 수삼에는 거의 존재하지 않는 $\mathrm{G}-\mathrm{Rg}_{3},-\mathrm{Rg}_{5},-\mathrm{Rg}_{6},-\mathrm{Rk}_{1},-\mathrm{Rk}_{3},-\mathrm{Rs}_{3},-\mathrm{Rs}_{4},-\mathrm{Rs}_{5},-\mathrm{F}_{4}$

Table 2. Variation of ginsenoside content $(\mathrm{mg} / \mathrm{g})$ in lateral root of 6-year-old ginseng during steaming process of red ginseng ${ }^{21)}$

\begin{tabular}{|c|c|c|c|c|}
\hline & \multicolumn{4}{|c|}{ steaming time (hrs) } \\
\hline & 0 & 1 & 2 & 3 \\
\hline Total & 35.439 & 42.113 & 57.974 & 50.332 \\
\hline Diol & 21.768 & 28.488 & 43.063 & 36.974 \\
\hline Triol & 11.569 & 11.505 & 12.533 & 11.237 \\
\hline Diol/Triol & 1.867 & 2.476 & 3.436 & 3.290 \\
\hline Ginsenoside-Ro & 2.012 & 2.120 & 2.378 & 2.121 \\
\hline $\mathrm{Rb}_{1}$ & 8.097 & 10.880 & 16.016 & 14.316 \\
\hline $\mathrm{Rb}_{2}$ & 5.531 & 7.230 & 11.352 & 9.282 \\
\hline $\mathrm{Rc}$ & 4.989 & 6.495 & 9.943 & 8.119 \\
\hline $\mathrm{Rd}$ & 1.251 & 1.629 & 2.310 & 1.864 \\
\hline $\operatorname{Re}$ & 4.779 & 4.105 & 5.223 & 3.720 \\
\hline Rf & 2.540 & 2.533 & 2.669 & 2.413 \\
\hline $\operatorname{Rg}_{1}$ & 3.859 & 4.335 & 3.723 & 3.971 \\
\hline 20(S)-Ginsenoside $\mathbf{R g}_{1}$ & 0.481 & 0.468 & 0.700 & 0.589 \\
\hline 20(R)-Ginsenoside $\mathrm{Rg}_{2}$ & - & - & 0.042 & 0.125 \\
\hline 20(S)-Ginsenoside $\mathrm{Rg}_{3}$ & - & 0.093 & 0.221 & 0.408 \\
\hline 20(R)-Ginsenoside $\mathrm{Rg}_{3}$ & - & 0.054 & 0.140 & 0.262 \\
\hline 20(S)-Ginsenoside $\mathrm{Rh}_{1}$ & - & 0.064 & 0.134 & 0.277 \\
\hline 20(R)-Ginsenoside $\mathrm{Rh}_{1}$ & - & - & 0.042 & 0.142 \\
\hline Ginsenoside $\mathrm{Rs}_{1}$ & 1.143 & 1.105 & 1.577 & 1.233 \\
\hline Quinquenoside- $R_{1}$ & 0.757 & 1.002 & 1.504 & 1.490 \\
\hline
\end{tabular}

Values are average after three measurements, and minus(-) means undectectable. 
와 함께 $20(\mathrm{R})-\mathrm{Rg}_{2},-\mathrm{Rh}_{1},-\mathrm{Rg}_{3}, \mathrm{Rs}_{3}$ 등이 생성된다. ${ }^{100)}$ 특히, 이중 $20(\mathrm{~S})+20(\mathrm{R})-\mathrm{Rg}_{3}, \mathrm{G}-\mathrm{Rg}_{5}, \mathrm{G}-\mathrm{Rk}_{1}$ 가 다량 생성되어 각각 총 진세노사이드 함량의 $44 \%, 24 \%, 21 \%$ 를 차지하였다.

필자도 동일한 재배포장에서 생산된 수삼(4년근 세근)을 원 료로 홍삼과 백삼을 제조하여 사포닌 함량 과 그 조성변화를

Table 3. Predicted residual ratio $(\%)$ of malonyl-ginsenosides in lateral root of 6-year-old ginseng by steaming process of red ginseng $^{21)}$

\begin{tabular}{ccccc}
\hline & \multicolumn{4}{c}{ steaming time (hrs) } \\
\cline { 2 - 5 } & 0 & 1 & 2 & 3 \\
\hline Malonyl-ginsenoside- $\mathrm{Rb}_{1}$ & 100 & 49 & 35 & 12 \\
$\mathrm{Rb}_{2}$ & 100 & 53 & 50 & 26 \\
$\mathrm{Rc}$ & 100 & 46 & 35 & 11 \\
$\mathrm{Rd}$ & 100 & 49 & 36 & 13 \\
\hline
\end{tabular}

Values are average after three measurements.
비교 하였다. Table 4 에서와 같이 분석된 11종의 진세노사이 드 총 함량은 관행제조 홍삼이 $8.54 \%$ 로서 백삼의 $8.19 \%$ 보 다 많았다. 특히 $\mathrm{G}-\mathrm{Rh}_{1}, \mathrm{Rh}_{2}, \mathrm{Rg}_{3}$ 성분 함량은 백삼보다 홍 삼 $\left(98^{\circ} \mathrm{C}\right.$ 에서 2 시간 증삼 $)$ 에서, 특히 고온으로 증삼제조 $\left(120^{\circ} \mathrm{C}, 3\right.$ 시간 증삼)한 홍삼에서 그 함량 증가가 현저하였다. 이에 반해 특히 고온으로 열처리 한 경우는 상대적으로 $\mathrm{PD}$ 계의 $\mathrm{G}-\mathrm{Rb}_{1}, \mathrm{G}-\mathrm{Rb}_{2}, \mathrm{Rc}$ 등과 $\mathrm{PT}$ 계 $\mathrm{G}-\mathrm{Re}$ 함량이 백삼에 비해 현저히 감소되었다. 그런데 수삼으로부터 홍삼제조 수율 은 관행방법으로 제조된 홍삼이 $24.3 \%$ 인데 비해 고온 증삼의 경우는 $20.7 \%$ 로 약 $17 \%$ 정도 적었다. 그러나 $\mathrm{G}-\mathrm{Rh}_{2}$ 와 G$\mathrm{Rg}_{3}$ 함량은 현저히 증가되었다.

또한 Matsuda 등23)은 홍삼과 백삼(박피한 건조인삼)의 $70 \%$ 메탄올 엑스의 제조수을은 홍삼이 $32.0 \%$, 백삼이 $19.9 \%$ 이었고, 이들 엑스의 HPLC 분석법에 의한 개별 $\mathrm{G}_{-} \mathrm{Rb}_{1}$, $-\mathrm{Rb}_{2},-\mathrm{Rc},-\mathrm{Rd},-\mathrm{Re},-\mathrm{Rg}_{1}$ 의 총 함량은 홍삼이 $10.242 \%$,

Table 4. Variation of ginsenoside content in fine root of 4-year-old ginseng by processing (\%)

\begin{tabular}{ccccccccccccc}
\hline \hline & $\mathrm{Rb}_{1}$ & $\mathrm{Rb}_{2}$ & $\mathrm{Rc}$ & $\mathrm{Rd}$ & $\mathrm{Re}$ & $\mathrm{Rf}$ & $\mathrm{Rg}_{1}$ & $\mathrm{Rg}_{2}$ & $\mathrm{Rg}_{3}$ & $\mathrm{Rh}_{1}$ & $\mathrm{Rh}_{2}$ & $\mathrm{Total}$ \\
\hline $\mathrm{WG}$ & 1.805 & 2.137 & 1.509 & 0.406 & 1.340 & 0.307 & 0.537 & 0.109 & 0.038 & 0.006 & - & 8.194 \\
$\mathrm{RG}^{\mathrm{a})}$ & 1.963 & 2.175 & 1.472 & 0.722 & 1.108 & 0.243 & 0.492 & 0.131 & 0.115 & 0.121 & 0.003 & 8.542 \\
$\mathrm{RG}^{\mathrm{b})}$ & 1.005 & 1.293 & 0.879 & 0.645 & 0.335 & 0.379 & 0.239 & 0.698 & 2.193 & 0.423 & 0.101 & 8.190 \\
\hline
\end{tabular}

WG: white ginseng; RG: red ginseng; a): Ordinary processing of red ginseng (steamed for 2 hrs at $98^{\circ} \mathrm{C}$ ), b) Steamed for 3 hrs at high temperature $\left(120^{\circ} \mathrm{C}\right) ;-:$ undetectable

Table 5. 홍삼특유 ginsenosides 의 약리 활성

\begin{tabular}{|c|c|}
\hline 구 분 & 밝혀진 주요 약리효과 \\
\hline $\mathrm{G}-\mathrm{Rh}_{2}$ & $\begin{array}{l}\text { - 암세포의 증식억제 및 형태적 기능적 정상세포로 분화유도 }{ }^{25-28)} \\
\text { - 암세포의 능동적 세포사멸(apoptosis) 유도 }{ }^{29,30)} \\
\text { - 난소암 발생억제 및 병용 시 항암제 효과 증강 } 31) \\
\text { - 항암제의 항암활성 증대,32) }\end{array}$ \\
\hline $\mathrm{G}-20(\mathrm{~s})-\mathrm{Rg}_{3}$ & 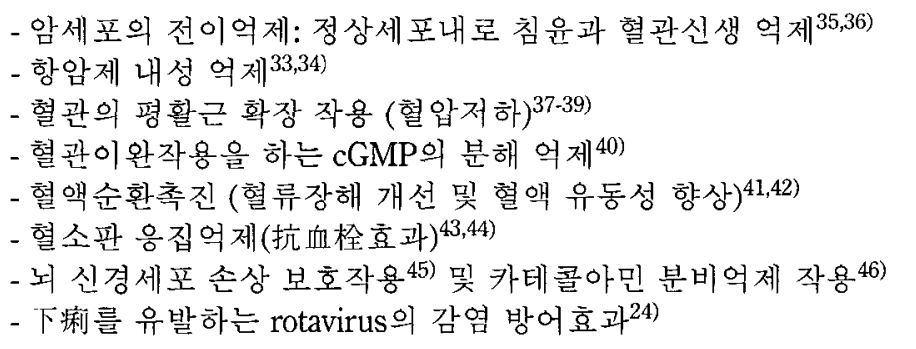 \\
\hline $\mathrm{G}-\mathrm{Rs}_{4}$ & $\begin{array}{l}\text { - 인체간암세포의 증식억제 }{ }^{47)} \\
\text { 능ㅇ동적 세포 사멸 유도 }\end{array}$ \\
\hline $\mathrm{G}-\mathrm{Rg}_{5}$ & $\begin{array}{l}\text { - 인체 간암세포의 증식억제 }{ }^{48)} \\
\text { 암세포의 DNA합성억제 }\end{array}$ \\
\hline $\mathrm{G}-\mathrm{Rh}_{4}$ & $\begin{array}{l}\text { - 인체 폐암, 백혈병, 혹색종양 암세포 둥의 증식억제 }{ }^{49)} \\
\text { - 동물 백혈병 암세포 중식억제 }{ }^{49)}\end{array}$ \\
\hline
\end{tabular}


백삼이 $8.102 \%$ 이었다고 보고하였다. 이는 시료로 사용된 홍 삼과 백삼은 동일한 원료 수삼으로 제조된 것은 아니었다. 특 히 이상에서와 같이 대부분의 사포닌 함량조사에서 홍삼에 비 해 백삼의 사포닌 함량이 적은 것으로 보여 지고 있는데, 이 에 대해서는 백삼 특유 사포닌인 M-G의 분석이 배제되었음 에 유의할 필요가 있다.

3) 홍삼특유 사포닌의 약리활성: 지금까지 밝혀진 $\mathrm{G}-\mathrm{Rh}_{2}$ 를 비롯한 홍삼특유 GS의 주요 약리활성을 Table 5에 요약하였 으며, 이들 성분은 항암 및 암예방 효과와 순환기 질환에 유 호성을 시사하는 약리활성을 가지고 있다는 것이 특징적이었 다. 특히 이중에서 $\mathrm{G}-\mathrm{Rg}_{3}$ 의 rotavirus 감염방어 활성과 구조 상관에 대한 검토결과, 홍삼 특유 성분인 $20(\mathrm{~S})-\mathrm{G}-\mathrm{Rg}_{3}$ 투여에 서는 현저한 감염방어 효과가 인정되었으나 그 구조 이성체인 백삼에서 발견되는 $20(\mathrm{R})-\mathrm{G}-\mathrm{Rg}_{3}$ 에서는 그 효과가 인정되지 않아 구조-활성과의 상관성이 있는 것으로 여겨지고 있다. ${ }^{24)}$

\section{4. 캬사포넌계 성분}

\section{1) Polyacetylene계 성분}

현재 20 여종이 발견되고 있는데 이들 성분은 대부분 암세포 에 대한 세포독성을 나타냄으로서 암세포의 증식을 억제하는 작용이 있다. $\left.{ }^{9}, 50\right)$ 이중 대표적 인삼의 폴리아세칠렌 성분으로는 panaxydol, panaxynol, panaxytriol 3종이 있으며 panaxytriol은 홍삼제조 과정 중 panaxydol로부터 생성되는 홍삼 특유 성분으 로 밝혀지고 있다. ${ }^{13,51)}$ 이 성분은 수종 암세포에 대해 선택적 독성을 발현하고, 암세포(B16 melanoma)를 이식한 마우스에 서 panaxytriol의 경구투여 $(60 \mathrm{mg} / \mathrm{kg})$ 시 종양 증식 억제 효 과를 나타내고, 항암제(Mitomycin C, 5-Fu, CDDP)와 병용
시는 항암활성이 증강됨이 관찰되었다. 이러한 항암제의 효과 상승기전으로는 panaxytriol 성분이 암세포의 막유동성(膜流動 性)을 저하시킴으로서 항암성분을 암세포내로 유입의 촉진 또 는 축적을 증강시키는 호과 등으로 해석되고 있다. ${ }^{52,53)}$

한편 인삼에서 분리된 acetylenic compounds 중에서 일부 성분은 in vitro에서 설치류나 사람의 암세포 종류에 따라 항암 제인 5-flurouracil(5-Fu)과 cisplatin(CDDP)보다 강한 증식억제 활성을 보였고, 그 중 panaxydolo 가장 강한 세포독성을 나타 내었다. 암세포에 대한 panaxydol의 $\mathrm{IC}_{50}(\mu \mathrm{M})$ 은 인체유방암세 포(MCF7): 11.5(CDDP: 35.0), 인체자궁암세포(HeLa): 38.4 (5-Fu: >50), 설치류 L1210:0.19(CDDP:1.2), 마우스 섬 유종(NIH/3T3) : 1.3(5-Fu:2.8), Kirsten murine sacorma Virus-transformed NIH/3T3(DT) : 0.65(5-FU : 1.1)이었다. ${ }^{50)}$ 그 러나 in vivo에서 이러한 항암제와의 효과비교는 거의 조사되 지 않았다.

\section{2) 산성다당체 성분(Acidic polysaccharide)}

인삼 다당체 성분은 체지방 분해작용과 암환자의 식욕감퇴 및 체중감소를 일으키는 독소홀몬(toxohormone-L)에 대해 길 항적 작용을 나타내며, 인삼 산성다당체 성분 (pectin-like $\alpha-1$, 4-polygalturonan 골격을 가지고 있음)의 함량은 홍삼이 4-7\% 로 백삼의 0.6-0.8\%에 비해 약 8배 정도 함량이 높았다. ${ }^{54,55)}$

홍삼 중에는 주로 uronic acid로 이루어진 산성다당체가 함 유되어 있으며, uronic 함량은 재배인삼에서 연근이 증가할수 록 많아져 6 년 근에서 가장 높은 함량을 보였다. ${ }^{56)}$ 부위별로 는 사포닌 함량 분포와는 상반되게 세근이나 인삼근의 푀충부 위 보다는 내부 중심부에 그 함량이 높은 것이 특징적이다.

또한 산성다당체 성분은 항암 면역증강효과를 가지고 있다는

Table 6. Comparison of Acidic polysaccharide contents in red ginseng and ginseng varieties ${ }^{60)}$

\begin{tabular}{|c|c|c|}
\hline & \multicolumn{2}{|c|}{ Acidic polysaccharde fraction } \\
\hline & content $(\mathrm{w} / \mathrm{w}, \%)$ & relative content \\
\hline red ginseng & & \\
\hline main root ${ }^{(1)}$ & $8.3 \pm 0.9 \%^{a . b}$ & $100 \%$ \\
\hline lateral root(Large $)^{(2)}$ & $6.7 \pm 0.5 \%$ & $81.6 \%$ \\
\hline lateral root(small $)^{(3)}$ & $6.2 \pm 0.8 \%$ & $75.1 \%$ \\
\hline fine root(large $)^{(4)}$ & $5.7 \pm 1.0 \%$ & $68.7 \%$ \\
\hline fine $\operatorname{root}(\mathrm{small}){ }^{(5)}$ & $5.6 \pm 0.6 \%$ & $67.3 \%$ \\
\hline white ginseng & $4.9 \pm 0.6 \%$ & $59.3 \%$ \\
\hline American ginseng ${ }^{(6)}$ & $4.4 \pm 0.8 \%$ & $53.5 \%$ \\
\hline Sanchi ginseng ${ }^{(7)}$ & $3.7 \pm 0.2 \%$ & $44.6 \%$ \\
\hline
\end{tabular}

1) $13.79 \pm 2.59 \mathrm{~cm}, 2) 8.27 \pm 0.80 \mathrm{~cm}, 3) 5.42 \pm 0.73 \mathrm{~cm}, 4) 2.83 \pm 0.45 \mathrm{~cm}, 5) 1.5 \mathrm{~mm}$ 이 하 6) Panax quinquefolium, 7) Panax notoginseng, a) Acidic polysaccharide was determined by carbazole- $\mathrm{H}_{2} \mathrm{SO}_{4}$ method using glucuronic acid as a reference standard, b) the results were represented as the mean \pm S.D. of triplicate experiments. 
것이 in vitro와 in vivo 시험에 의해 밝혀지고 있으며,57-59) galacuronic acid를 표준물질로 하여 carbazole- $\mathrm{H}_{2} \mathrm{SO}_{4}$ 방법으로 홍삼과 백삼의 산성다당체 함량 비교결과 Table 6 에서와 같이 홍삼이 $6.2-8.3 \%$ 인 것에 비해 백삼은 $4.9 \%$ 정도로 역시 홍삼 의 산성다당체 함량이 높았다. ${ }^{60)}$

홍삼에서 그 함량이 많은 것은 홍삼제조과정 중 열처리와 반복되는 탈수과정을 통한 당의 가수 분해반응으로 그 함량 이 증가되는 것으로 추정되나 정확한 생성기전은 밝혀지고 있 지 않다.

최근 홍삼으로부터 분리된 다당체 성분이 장관내에서 아미 라제 활성을 저해하여 포도당의 흡수를 지연시키고, 또한 췌 장 리파제와 골레스테롤에스트라제의 저해를 통해 지방이나 콜레스테롤 흡수를 저해시키는 생리활성이 있다는 것이 밝혀 져 비만증이나 당뇨병, 고지혈증 개선에 유용한 효과를 미칠 가능성이 시사되었다. ${ }^{61)}$

한편 Okuda 등 ${ }^{57)}$ 은 Galambos 방법에 의해 uronic acid 를 표준물질로 하여 일본에서 시판되는 홍삼분말 제품의 산 성다당체 함량을 분석한 결과 $3.5 \sim 2.08 \%$ 로서 차이가 있음을 보고하였다.

그런데 인삼 중 산성 다당체 함량은 시료의 추출 및 분석 방법 등에 따라 차이가 있을 수 있으나 홍삼 중 산성다당체 함량은 사포닌 함량 정도로 많이 함유된 성분으로서, 그 생리 활성도 밝혀지고 있으므로 사포닌 이외 품질지표 성분으로 활 용도 기대할 수 있을 것이다.

\section{3) 아미노산과 그 유도체 성분}

인삼 중에는 약 $2 \%$ 정도의 유리아미노산이 함유되어 있으 며, 그 함유조성은 연구자에 따라 다소 차이가 있으나 총 아 미노산 중 arginine의 조성비율이 약 $60-70 \%$ 로 높다는 것이 특징적이다. ${ }^{60)} \mathrm{Li}$ 등은 수삼을 홍삼으로 제조하면 아미노산 총 함량이 감소되고(7.7-10.4\%), glutamic acid도 약간 감소 된다고 보고하였다. ${ }^{3)}$ glutamic acid는 $\alpha$-aminodicaboxylic acid로서 홍삼제조 과정 중 열처리를 받으면 탈수 $\left(-\mathrm{H}_{2} \mathrm{O}\right)$ 등의 반응에 의해 pyro-glutamic acid로 된다. ${ }^{3)}$ pyro-glutamic acid는 홍삼 중에 약 $0.3 \%$ 정도 함유되어 있으며, 인슐린 유 사작용을 나타내는 항당뇨 활성 ${ }^{62)}$ 과 혈압저하작용과 관련 있 는 angiotension converting enzyme(ACE)의 활성을 억제하 는 약리활성 ${ }^{56)}$ 이 보고되었다.

수삼을 쪄서 건조하는 홍삼의 제조과정에서 열처리에 의해 당(糖)과 아미노산의 결합 반응(amino-carbonyl reaction)인 Maillard 반응이 일어나 아미노산 유도체가 생긴다는 것이 밝 혀졌다. 즉, 수삼 중의 알기닌(arginine)과 맥아당(maltose)이 결합하여 아미노산 유도체인 Maltulosyl arginine이 생성되며,
이 성분 중의 하나는 Arginine-Fructose-Glucose (Agr-Fru$\mathrm{Glc}$ )로서, 이 성분의 함량은 백삼보다 홍삼에서 현저히 높다 는 것이 밝혀졌다(홍삼 $5 \%>$ 백삼 $0.2 \%$ 이하 $)^{52)}$. Agr-Fru$\mathrm{Gl}$ 가 생성되는 Maillard 반응 조건은 수분함량이 적고 산도 가 낮은 산성조건 하에서 잘 일어나므로 같은 열처리라 하더 라도 수삼을 물로 끊일 때보다는 수증기로 찐 후 건조과정을 거치는 홍삼제조 시에 Maillard 반응이 잘 일어날 수 있다. ${ }^{61)}$

$\mathrm{Okuda}^{57) ㄴ ㅡ ㄴ ~ A g r-F r u-G l c ㅇ ㅢ ~ ㅇ ㅑ ㄱ ㄹ ㅣ ㅎ ㅘ ㄹ ㅅ ㅓ ㅇ ~ ㄱ ㅓ ㅁ ㅅ ㅐ ㄱ ㅇ ㅡ ㄹ ~ ㅇ ㅟ ㅎ ㅐ ~ ㄷ ㅗ ㅇ ㅁ ㅜ ㄹ ㅅ ㅣ ㄹ ㅎ ㅓ ㅁ ~}$ 을 통해 이 성분을 경구로 섭취하면 소장에서 matase에 의 해 말단의 glucose가 유리되어 Arg-Fru로 되어 장관에서 흡 수된다고 보고하였다. Arg-Fru를 정맥 주사하면 세동맥의 혈 류 속도가 증가한다 것이 발견되었는데, 이는 Arg-Fru가 세 동맥의 내피세포에 있는 nitric oxide(NO) 합성효소의 작용을 받아 NO생성에 관여하여 세동맥을 확장시켜 혈류가 촉진되 는 것으로 여겨지고 있다. 또한 Agr-Fru-Glc는 말타제 효소 활성을 억제하는 생리활성을 가지고 있어 장관에서 포도당의 흡수를 억제 또는 지연시킴으로써 급속한 혈당상승을 억제하 여 항미만(抗肥滿)효과를 발현할 가능성이 시사되었다. ${ }^{61,63)}$

홍삼과 백삼의 유리아미노산의 함량을 비교하면 백삼이 홍 삼보다 현저히 많다(백삼 : $2990.3 \mathrm{mg} \%$; 홍삼 : $804.7 \mathrm{mg} \%$ ). ${ }^{64)}$ 이는 수삼을 홍삼으로 제조 시 전술한 바와 같이 열처리 반 웅에 의해 유리아미노산이 새로운 아미노산 유도체의 생성에 이용됨으로 홍삼 중 총 유리아미노산 함량은 현저히 감소되 는 것으로 이해된다. 예를 들면 홍삼제조 시 수삼 중 가장 많이 함유된 유리아미노산인 arginine이 당과 결합하여 아미 노카보닐 반응생성물(Agr-Fru-Glc)을 만들고, glutamic acid가 pyroglutamic acid로 변환됨으로 유리아미노산의 절대적 감소 라기보다는 상기와 같은 약리활성 물질의 생성에 이용되는 것 으로 보아야 할 것이다.

또한, 홍삼제조 시 증숙 과정 중 맥아당이 아미노산과 Maillard 반응에 의해 비(非)배당체 성분으로 백삼에는 함유되 어 있지 않는 홍삼 특유 성분인 말톨(maltol)이 생성된다. 생 성 기전은 맥아당이 아미노산과 반응해서 4-0- $\alpha$-D-glucosyl1-deoxy-2,3-diketosaccharide를 생성하고 이 화합물은 불안정 하므로 2-ketone group과 C-6-hydroxyl group이 cyclization 되어 glycoside $\mathrm{B}$ 로 되며 Glycoside $\mathrm{B}$ 는 다시 rearrangement 및 당의 이탈로 되어 말톨(maltol)이 되는 것으로 보고되고 있다. ${ }^{3)}$ 그러나 말톨은 백삼제조 시 열풍 건조와 같 은 열처리가 가해지면 미량 생성될 수도 있다. 말톨은 생체 노화와 관련된 지질의 과산화를 억제하는 항산화 활성이 있 음이 밝혀졌다. ${ }^{65)}$

인삼 중에 비단백질 아미노산인 $\beta-N-o x a l o-L-\alpha, \beta$-diaminopropionic acid( $\beta$-N-ODAP)의 구조를 가진 dencichine 성분이 
함유되어 있다. ${ }^{66,67)}$ dencichine은 Rao 등(1964)이 Lathyrus sativus의 종자로부터 신경독의 원인 물질(neurotoxin)로 처음 분리하였다. ${ }^{68)}$ dencichine은 백삼(0.29-0.31\%)보다는 홍삼 $(0.02-0.12 \%)$ 에 함량이 적으며, 부위별 함량 분포가 달라서 뇌 두 $(0.76 \%)$ 와 세근 $(0.52 \%)$ 에 함량이 높고 주근 $(0.16 \%)$ 에는 적은 것으로 보고 되었다. ${ }^{66)}$ 홍삼에서 함량이 적은 것은 dencichine이 dicarboxylic acid로서 열에 불안정하여 수삼을 홍삼으로 제조할 때 열처리에 의해 2,3-diamino-propyl aldehyde carboxylic acid로 분해 되어 그 함량이 적어진다. dencichine의 생리활성은 지혈작용과 신경독(neurotoxin) 작용 66,68$)$ 이외에 이 성분의 생리활성 조사에서 histamine 처리로 유도 되는 기니픽 대동맥의 수축을 더욱 증가시키는 효과를 보였으 나 norepinephrine 유도 혈관 수축반응에는 영향을 미치지 않은 것으로 관찰되었다. ${ }^{56)}$

특히 신경독 물질인 이 성분은 홍삼제조 시 함량 감소가 일어남으로 그 독성도 감소될 수 있다. ${ }^{3)}$ 한방에서 뇌두는 최 토작용이 있다고 하여 제거하고 사용한다고 하는데 이는 아 마도 뇌두에 신경 독성을 나타내는 dencichine 함량이 높은 것과 관련이 있는 것으로 여겨진다.

\section{약리효능 비교}

\section{1. 순환기계에 미치는 효능}

김 등69)은 혈압에 미치는 인삼의 초기 연구에서 6 년근 홍 삼과 백삼의 ether 엑기스 및 총사포닌 분획의 효과를 조사하 였다. 홍삼과 백삼의 ether 엑기스 $(10 \mathrm{mg} / \mathrm{kg})$ 및 총사포닌 $(50 \mathrm{mg} / \mathrm{kg})$ 을 고양이에 정맥투여 시 홍삼이 백삼에 비해 혈 압 강하 효과가 현저함이 관찰되었다. 혈압강하 정도는 홍삼 의 사포닌 분획이 백삼 사포닌 분획보다 크고, 혈압강하 지속 시간은 ether 엑기스가 사포닌 분획보다 길었다. 그 후 동 저 지들은 백삼보다 홍삼 중에 함량이 높은 $\mathrm{G}-\mathrm{Rg}_{3}$ 가 혈압조절에 밀접히 관여하는 혈관내피의존적 이완반응을 촉진하여 순환기 계에 유용한 효과를 나타내는 주요 활성성분임을 밝혔다. ${ }^{37,38}$

Matsuda 동 23$)$ 은 홍삼의 $70 \%$ 메탄올 엑스에서 혈류중가작 용, 항혈전 및 선용계 활성화작용을 지표로 한국산 6 년근 홍 삼과 백삼(외피제거)의 $70 \%$ 메탄올 엑스를 시험재료로 하여 홍삼과 백삼의 악리활성을 비교하였다. 그 결과 홍삼엑스는 정 상랫드와 serotonin( $20 \mathrm{mg} / \mathrm{kg}$, s.c.) 이나 endotoxin $(0.1 \mathrm{mg}$ $\mathrm{kg}, i . v$ ) 처리 랫드에서 저하된 주요 장기 조직(신조직, 위점 막, 간조직등)의 혈류를 증가시키며, 혈액응고를 억제하고 선 용계의 활성화작용을 보여주었다. 이러한 실험모델에서 그 호 과는 홍삼엑스가 백삼 엑스보다 강한 것으로 관찰되었다. ${ }^{23,70)}$

최근 동 저자 둥 71$)$ 은 랫드를 이용한 실험적 혈류장해 실험
모델을 이용하여 홍삼과 백삼의 $70 \%$ 메탄올 엑스의 효과를 비교하였다. 그 결과 norepinephrine 처리 $(0.4 \mathrm{mg} / \mathrm{kg}, i . v$.$) 에$ 의한 피부 혈류저하가 홍삼투여 $(200,500 \mathrm{mg} / \mathrm{kg}$, p.o. $)$ 로 유의 하게 회복되었으나 백삼엑스 투여에서는 그 회복 효과가 미 약하였다. 또한 피부혈류를 촉진하는 활성성분의 탐색을 위해 홍삼과 백삼의 각각의 사포닌 분획과 비사포닌 분획(사포닌을 함유하지 않은 수용성 물질)을 나누어 효과를 비교한 결과, 사포닌분획에서 만이 유호성이 인정되었으나 그 효과는 홍삼 엑스에 미치지 못하였다. 또한 상호 병용에 의한 효과 비교결 과, 홍삼사포닌 분획에 홍삼비사포닌 분획을 병용하면 그 효 과가 더욱 증강되었으나 백삼으로부터 분리된 비사포닌 분획 을 첨가 시는 유의한 증강효과는 관찰되지 않았다. 그러나 백 삼사포닌 분획에 홍삼비사포닌 분획 첨가시는 역시 피부 혈 류저하가 회복되는 효과를 보였다. 이러한 결과로부터 사포닌 의 피부혈류 개선작용을 증강시키는 비사포닌 성분이 홍삼의 가공과정 중에 생성된다는 것이 시사되었고, 아울러 홍삼의 약효발현에는 사포닌뿐만 아니라 비사포닌분획도 중요한 역 할을 한다는 것이 제시되었다. ${ }^{70,71)}$

\section{2. 항발압작용과 면역기능에 대한 효능 1) 항발암작용}

Yun 등 ${ }^{72}$ 은 발암물질인 benzo(a)pyrene $(\mathrm{B}(\mathrm{a}) \mathrm{P})$ 를 마우스 에 주사하여 폐선종(肺腺腫)을 유발시키는 중기(9주) 항발암 실험법을 이용하여 인삼의 년근별(1.5, 3, 4, 5 및 6년근)및 가공 형태별 항발암활성을 비교하였다. 가공 형태별 시료는 수삼은 건조수삼으로 하고, 백삼은 1.5 년근을 제외하고는 껍 질을 제거하여 건조하고, 홍삼은 수삼을 증숙하여 건조한 것 을 사용하였다. 항발암성 비교는 각각의 연근별 수삼, 백삼, 홍삼을 분말과 수용성추출물(water soluble extract)로 구분하 여 효과를 비교하였다. 발암물질인 $\mathrm{B}(\mathrm{a}) \mathrm{P}$ 를 신생마우스에 대 량(통상 용량의 10 배)으로 피하주사 $(0.5 \mathrm{mg} / \mathrm{g}$ mouse체중) 하고 3 주 후 이유시부터 상기 각각의 인삼시료를 급수에 용 해하여 투여하고 폐선종의 발생율을 $\mathrm{B}(\mathrm{a}) \mathrm{P}$ 단독투여군인 대 조군과 비교 관찰하였다. 그 결과 건조수삼의 분말과 추출물 에서는 6 년 근에서만 항발암효과가 나타났고, 백삼분말은 5 , 6 년 근에서, 백삼 추출물은 6 년 근에서, 홍삼의 분말과 추출 물은 $4,5,6$ 년 근에서 항발암 작용이 관찰되어 수삼이나 백 삼보다는 홍삼이 더 유의적인 항발암 효과가 있음을 보여주 었다(Table 7).

한편, 이들 인삼시료 중의 주요 ginsenosides $\left(\mathrm{G}-\mathrm{Rb}_{1},-\mathrm{Rb}_{2}\right.$, $-\mathrm{Rc},-\mathrm{Rd},-\mathrm{Re},-\mathrm{Rf},-\mathrm{Rg}_{1}$ ) 함량은 홍삼보다는 수삼이나 백삼 이 약간 높은 경향을 보였고, 연근이 증가함에 따라 다소 높 은 경향을 보였다. 그러나 조사된 이러한 ginsenosides 함량 
Table 7. Effects of ginseng on incience of lung adenoma in mice induced by benzo (a) pyrene (BP) ${ }^{72)}$

\begin{tabular}{|c|c|c|c|c|c|c|}
\hline & \multicolumn{6}{|c|}{ Incidece of lung adenoma(\%) } \\
\hline & \multicolumn{2}{|c|}{ Fresh ginseng } & \multicolumn{2}{|c|}{ White ginseng } & \multicolumn{2}{|c|}{ Red ginseng } \\
\hline & Powder & Extract & Powder & Extract & Powder & Extract \\
\hline $\begin{array}{l}\text { Unteated } \\
\text { Control }\end{array}$ & 1.4 & 0 & 0 & 0 & 0 & 0 \\
\hline $\mathrm{BP}$ alone & 41.3 & 63.9 & 45.0 & 41.3 & 48.6 & 47.5 \\
\hline $\begin{array}{l}\text { BP+3-years } \\
\text { BP+4-years } \\
\text { BP+5-years } \\
\text { BP+6-years }\end{array}$ & $\begin{array}{l}30.0 \\
31.3^{\text {a) }} \\
30.3^{\text {a) }} \\
27.8^{\text {b) }}\end{array}$ & $\begin{array}{l}52.5^{\mathrm{a})} \\
51.8^{\text {a) }} \\
47.5^{\mathrm{a})} \\
44.1^{\mathrm{bj}}\end{array}$ & $\begin{array}{l}41.3^{\mathrm{a})} \\
38.0^{\mathrm{a})} \\
31.6^{\mathrm{b})} \\
25.4^{\mathrm{cj}}\end{array}$ & $\begin{array}{l}32.0^{\mathrm{a})} \\
46.0^{\mathrm{a})} \\
44.0^{\mathrm{c})} \\
26.5^{\mathrm{c})}\end{array}$ & $\begin{array}{l}41.7^{\text {a) }} \\
31.7^{\text {b) }} \\
28.3^{\text {b) }} \\
25.4^{\text {c) }}\end{array}$ & $\begin{array}{l}35.0^{\mathrm{a})} \\
30.1^{\mathrm{c})} \\
30.0^{\mathrm{c})} \\
26.3^{\mathrm{c})}\end{array}$ \\
\hline
\end{tabular}

${ }^{\mathrm{a}} \mathrm{P}>0.05,{ }^{\mathrm{b})} \mathrm{P}<0.05,{ }^{\mathrm{c})} \mathrm{P}<0.01$ vs BP alone; 0 본 표는 윤택구 등 ${ }^{72)}$ 의 자료롤 요약 정리

과 발암억제 효과 간에는 뚜렷한 관련성은 발견되지 않았다.

또한 최근 동 저자 등 ${ }^{73)}$ 은 홍삼의 효과가 우수한 것은 홍 삼의 제조과정 중에 생성되는 미량 ginsenosides에 기인 될 수 있을 것으로 추정하고 홍삼으로부터 $\mathrm{G}-\mathrm{Rh}_{1}, \mathrm{G}-\mathrm{Rh}_{2}, \mathrm{G}-$ $\mathrm{Rg}_{3}, \mathrm{G}-\mathrm{Rg}_{5}$ 등 4 종을 분리하여 중기 항발암성 시험을 실시 하였다. 그 결과 $\mathrm{G}-\mathrm{Rg}_{3}$ 와 $\mathrm{G}-\mathrm{Rg}_{5}$ 의 투여 시 유의한 폐선종 의 발생 억제 효과를 보였고, $\mathrm{G}-\mathrm{Rh}_{2}$ 에서도 감소경향이 관찰 되었다. 이로 미루어 홍삼의 항발암 작용 또는 암 예방 효과 는 이들 ginsenosides가 각각 단독 또는 복합적으로 작용하 여 약효를 발현하는 것으로 추정되었다.

Fukuchima 등 ${ }^{74)}$ 은 1,2-demethylhydrazine( $\left.\mathrm{DMH}\right)$ 으로 처리 로 유도되는 대장암 발생 모델을 이용하여 홍삼과 백삼의 항 발암 효과를 조사하였다. 인삼의 항발암 효과는 전암단계 지 표(preneoplastic marker)인 대장의 이상음와 병소(aberrant crypt foci: ACF)의 수와 5-bromo-2'-deoxyuridine (BrdU) 면역조직화학 검사를 통한 세포증식 정도(BrdU labeling index)로 평가하였다. 발암 유도를 위한 $\mathrm{DMH}$ 처리는 20 $\mathrm{mg} / \mathrm{kg}$ 용량으로 주 1 회, 4 주간 피하 주사하고, 홍삼과 백삼 은 사료의 $1 \%$ 용량으로 $\mathrm{DMH}$ 투여 전 1주일부터 5 주간 경구 투여하였다. 그 결과, 홍삼분말 투여군에서 현미경 관찰 을 통한 총 $\mathrm{ACF}$ 수의 유의한 감소와 특히 큰 $\mathrm{ACF}$ (병소당 4 개 이상의 음와: $\geq 4 \mathrm{crypts} / \mathrm{focus)}$ 수의 유의한 감소를 보였 다. 또한 $\mathrm{DMH}$ 처리 전 1 주부터 30 일간 홍삼과 백삼을 투여 한 결과, 홍삼 투여군에서 선종(腺腪)과 선암(腺癌)으로 진행 되는 초기 대장의 $\mathrm{ACF}$ 의 수가 유의하게 감소되었고, 대장 음와(colon crypts)의 $\mathrm{BrdU}$ labeling index(\%)의 유의한 감 소를 보였다. 그러나, 백삼 투여군에서는 이러한 효과가 발견 되지 않았다. 이러한 결과는 랫드 대장에서 $\mathrm{DMH}$ 유도 암화 과정의 개시단계에서 $\mathrm{ACF}$ 발생억제에 홍삼이 백삼보다 더 호과적임이 시사되었다. 그러나, 동 연구자들 ${ }^{75)}$ 에 의해 수행 된 중기 간(medium-term liver)과 다기관(multi-organ) 발암 성 검정 모델을 이용한 홍삼과 백삼의 발암억제 효과 조사에
서는 홍삼이 아닌 백삼 투여군에서 $\mathrm{ACF}$ 의 발생 수에는 영향 을 미치지 않았으나 소장과 결장의 선종(腺腫)의 발생이 유의 하게 감소되는 것이 발견되었다.

\section{2) 항암제의 항암활성에 미치는 효과}

항암제인 Mitomycin C(MMC)의 항종양 활성에 미치는 홍삼과 백삼의 $70 \%$ 메탄올 엑스의 호과가 비교되었다. ${ }^{76)}$ 인삼 추출물은 암세포 이식 후 2 일부터 시작하여 10 일 동안 매일 경구 투여 $(0.05,0.2,0.5 \mathrm{~g} / \mathrm{kg})$ 하고, $\mathrm{MMC}$ 는 암세포 이식 후 2 일부터 격일로 3 회 복강투여 $(0.01,0.05,0.1 \mathrm{mg} / \mathrm{kg})$ 하 고, 대조군은 생리식염수를 투여하였다.

그 결과 마우스 복수형 종양세포(Ehrich ascites carcinoma)와 랫드 복수간암세포(AH 130)에 대한 in vitro 시험 에서 항암제인 $\mathrm{MMC}$ 와 홍삼엑스를 병용 투여하면 $\mathrm{MMC}$ 단 독투여시 보다 항종양활성의 증강 호과가 관찰되었다. 홍삼엑 기스의 이러한 $\mathrm{MMC}$ 의 세포독성 증강효과는 배양된 종양세 포내로 $\mathrm{MMC}$ 성분의 유입을 촉진시키는 작용에 의해 발현되 며, 홍삼엑기스로부터 분리된 사포닌 성분중 $\mathrm{G}-\mathrm{Rg}_{3}$ 와 $\mathrm{G}-\mathrm{Rh}_{2}$ 가 암세포내로 $\mathrm{MMC}$ 의 유입을 유의적으로 촉진시키는 효과 가 있음이 확인되었다. Tong 등77)은 in vivo 시험에서 $\mathrm{MMC}$ 의 항종양효과 증강작용을 지표로 종양세포 $\left(5 \times 10^{6}\right)$ 를 이식한 실험동물을 대상으로 홍삼 과 백삼의 각각 $70 \%$ 메탄 올 엑기의 효과를 비교하였다. 그 결과 마우스 복수형 종양 (mouse Ehrich ascites carcinoma)과 랫드 복수간암(rat ascites hepatoma $\mathrm{AH}$ 130) 발생에 대해 백삼보다는 홍삼을 $\mathrm{MMC}$ 와 병용한 경우 강한 항종양효과를 보여 평균 생존일수 를 보다 유의하게 연장시켰다. 또한 홍삼과 백삼 투여군에서 종양세포의 lysosomal enzymes(Acid deoxytribonuclease, $\beta$-glucuronidase, acid phosphatase)의 호소 활성도 증가되었 는데 그 작용 강도는 홍삼이 백삼보다 강하였다.

또한 홍삼 특유 polyacetylenic alcohol 인 panaxytriol은 in vitro에서 사람의 위암세포(MK-1 cell line)에 $\mathrm{MMC}$ 의 세 
포 독성을 증강시키는 효과를 보였다. ${ }^{78)}$

또한 최근 홍삼으로부터 분리된 다당체 성분은 항암면역 증 강효과를 보여 암세포를 이식한 실험동물에 대해 종양 크기 의 감소와 종양 마우스의 평균생존일수를 현저히 연장시키는 항종효과를 보였고, 항암제인 Taxol과 병용시 Taxol의 항암활 성을 증강시키는 효과가 있음이 관찰되었다. ${ }^{103)}$

\section{3) 암세포 분비 독소호르몬(Toxohormone-L)의 억제작용}

독소호르몬(Toxohormone-L)은 간암환자의 복수로부터 악 액질(cachexia)을 일으키는 물질로부터 추출분리된 폴리펩티 드 (분자량 7 만 정도)로서 지방분해를 촉진하고 암환자의 식 욕감퇴와 체중감소를 유도하는 물질로 알려져 있다. ${ }^{79,80)}$ 인삼 의 산성다당체성분은 이 물질의 작용에 대한 길항적작용을 나 타내며, 홍삼(6년근)과 백삼으로부터 추출한 산성다당체 성분 의 Toxohormone-L에 대한 길항적 효과활성은 백삼보다 홍 삼이 2 배이상 강하며, 조(粗)산성다당체 성분의 추출수율도 홍 삼이 백삼보다 2-3배 정도 많았다. ${ }^{54)}$

\section{4) 감염방어 작용}

Matsuda 등 ${ }^{81)}$ 은 외부로부터 침입하는 이물질을 제거하여 면역기능을 담당하는 망내계의 탐식기능(reticuloendothelium system)에 미치는 홍삼과 백삼 $(70 \%$ 메탄올 추출물)의 효과를 비교하였다. 홍삼과 백삼 투여(각각 $50,200,500 \mathrm{mg} / \mathrm{kg}, 3$ 일간 경구투여)하고 carbon clearance test에 의한 이물질인 carbon의 제거 기능을 측정한 결과, 홍삼투여군 $(500 \mathrm{mg} / \mathrm{kg})$ 에 서 유의한 탐식지수의 증가를 보였다[대조군 4.91, 홍삼군 5.41 , 백삼군 5.06). 또한 in vitro 시험으로 복강 대식세포의 탐식기능에 미치는 효과비교에서도 이물질(異物質)인 latex의 탐식(phagocytosis of latex) 기능의 할성은 홍삼과 백삼 첨가 로 다같이 용량의존적 증가를 보였으나 그 효과는 홍삼에서 강하게 나타났다(대조군 100 에 비해 홍삼군 127 , 백삼군 119).

\section{5) 흥선 세포사(Thymus apoptosis) 억제효능}

면역기능에 관여하는 흥선세포의 세포사(cell death)에 미치 는 홍삼과 백삼의 조사사포닌 분획물의 영항을 비교하였다. ${ }^{82)}$ 우선 일차 배양한 흉선세포를 이용한 in vitro 시험결과, 홍 삼과 백삼 모두 덱사메타손(dexamethasone: DX) 처리로 유 도되는 흥선세포사를 유의하게 억제하는 효과가 관찰되었다. 그러나 in vivo 시험으로 마우스에 홍삼과 백삼 사포닌 분획 물을 투여 $(5 \mathrm{mg} / \mathrm{kg} / \mathrm{day}, 4$ 회 복강투여 $)$ 한 후 $\mathrm{DX}$ 투여(5 $\mathrm{mg} / \mathrm{kg}, 1$ 회 복강투여)로 유도되는 흥선의 세포사를 적출된 항선의 조직염색을 통해 관찰한 결과, 훙삼 사포닌분획 투여 군에서는 현저한 세포사의 억제효과가 관찰되었으나 백삼 투
여군에서는 그러한 유의적인 억제효과는 관찰되지 않았다.

\section{4. 노화역제 효능과 관련된 지질과산화억제 및 항산화 활 성능}

유리기(free radical)는 반응성이 강한 물질로서 생체 내에 서 지질과산화를 일으켜 조직의 병변이나 여러 장기에 장해 를 일으켜 생체노화의 요인으로도 작용한다는 것이 잘 알려 져 있다. Han 등 ${ }^{83)}$ 은 동물 및 in vitro 실험을 통해 인삼은 항산화 작용을 통해 항피로, 항노화작용을 비롯한 여러 가지 질병의 예방과 그 장해증상을 개선하는 호과를 나타내는 것 으로 보고하였다.

6년근 수삼과 백삼 및 홍삼의 $70 \%$ 에탄올 엑기스를 환쥐 에 6주간 경구 투여 $(200 \mathrm{mg} / \mathrm{kg})$ 한 후 휜쥐 간의 과산화 지 질 생성에 미치는 효과를 비교하였다. ${ }^{78)}$ 그 결과 백삼과 홍삼 모두 유의한 지질과산화 억제효과가 관찰되었는데 그 효과는 홍삼 투여군에서 강하게 나타났다.

또한 $45 \%$ 의 에탄올 투여 $(10$ 일간 투여)로 생기는 흰쥐의 간 과산화지질 함량 조사에서도 백삼보다는 홍삼 엑기스 투 여군에서 더욱 낮은 수치를 보였다.

한편, 항산화 활성 모델시험으로 free radical인 a, a'diphenyl- $\beta$-picrylnydrazyl(DPPH)를 이용하여 훙삼과 백삼의 $70 \%$ 에탄올 추출물에 대한 수소공여능을 측정하여 항산화 활 성을 비교한 결과, 백삼보다는 홍삼 추출물에서 매우 강한 수 소공여능을 보였다. 특히 홍삼 제조시 갈색화반응이 일어나는 데 이때 생기는 갈변물질은 매우 강한 항산화 호과를 보였으 며, 수소공여활성도 매우 강했다. 따라서 홍삼은 제조과정 중 갈색화 반응에 의해 생성된 갈변 물질의 함량이 백삼보다 많 아 홍삼에서 더욱 강한 항산화 활성을 발현하게 되는 것으로 여겨진다. ${ }^{8)}$

최근 김 등 ${ }^{84)}$ 은 $\mathrm{DPPH}$ 이용한 항산화 할성검정모델 시험을 이용하여 수삼의 증삼온도 조건을 달리하여 제조된 인삼추출 물(수포화 부탄올 추출물 분획물 수율: $13 \%$ )의 유리기 소거활 성(Radical-Scavenging Activity)을 조사하였다. 그 결과 $100^{\circ} \mathrm{C}$ 나 $110^{\circ} \mathrm{C}$ 보다 고온 조건인 $120^{\circ} \mathrm{C}$ 에서 제조된 인삼에 서 그 활성이 더욱 강하게 나타났고, 아울러 랫드 흥부대동맥 절편을 이용한 Organ chamber 시험에서도 역시 고온조건에서 제조된 인삼에서 내피의존성 이완반응이 가장 강하게 나타남 을 확인하였다. 그러나 이들 성분의 in vivo 효과는 아직 충분 히 검토되지 않았다. 또한 ginsenosides의 분석결과 수삼에 존 재하지 않은 홍삼특유 미량 생리활성 성분 ${ }^{35-38,48)}$ 인 $\mathrm{G}-\mathrm{Rg}_{3}$ 와 $\mathrm{G}-\mathrm{Rg}_{5}$ 의 함량이 고온 $\left(120^{\circ} \mathrm{C}\right)$ 증삼조건 하에서 현저히 증가되 었다. 반면 $\mathrm{G}-\mathrm{Rb}_{1}, \mathrm{G}-\mathrm{Rb}_{2}, \mathrm{G}-\mathrm{Rc}$ 등의 protopanaxadiol(PD) 계 사포닌 함량은 상대적으로 현저한 감소를 보였다. 이는 고 
온처리에 의한 $\mathrm{PD}$ 계 사포닌의 가수분해반응에 의한 구조전환 의 촉진으로 이들 홍삼특유 성분의 증가가 일어난 것으로 해 석된다.

한편 홍삼은 열처리에 의해 갈변반응과 함유성분의 변환이 일어남으로 인삼을 물에 끓인 탕액과 홍삼의 추출액과 어떤 차이가 있는지를 알아보기 위하여 수삼을 수증기 찐 다음 뜨 거운 물로 추출한 인삼 추출물과 인삼을 뜨거운 물로만 추출 한 인삼추출물을 대상으로 갈변화 정도와 유리기 소거활성을 검토하였다. ${ }^{85)}$ 그 결과 수증기로 찌는 것이 물 속에서 가열하 는 것보다 갈번화 반응이 더 많이 진행되며, 그 추출물의 항 산화 작용도 더 크다는 것이 밝혀젔다. 즉, 백삼을 수중기로 3 시간 찌는 것은 물속에서 45 시간 끓인 것과 비슷한 효과를 나타내었다. 이러한 결과는 인삼의 항산화 효과 면에서 수증 기로 찌는 것이 끓이는 것보다 더 효과적이라는 것을 암시해 준다.

\section{5. 알콜 해독관련 효소 활성에 미치는 효과}

알코올 대사에 미치는 효소활성에 미치는 효과조사를 위하 여 홍삼과 백삼 엑스를 토기에 투여한 후 간의 알콜 분해효 소인 (alcohol dehydrogenase) 활성도를 조사한 결과, 대조 군에 비해 백삼 및 훙삼엑스 투여군이 각각 $31 \%, 62 \%$ 의 효 소 활성도의 증가를 보여 홍삼 엑스 투여군에서 효소 활성이 강하게 나타났다. ${ }^{86)}$

또한 알코올 독성에 대한 홍삼과 백삼의 효과조사에서 각 각의 인삼엑기스를 마우스에 전처리한 후 알코올 평균 치사 량 $\left(\mathrm{LD}_{50}\right)$ 을 비교한 결과, 대조군의 $\mathrm{LD}_{50}$ 이 $63.3 \mathrm{mg} / 10 \mathrm{~g}$, b.w. 인데 비해 홍삼 및 백삼엑스 투여군은 대조군 대비 각각 $21 \%, 31 \%$ 의 증가를 보여 알코올 독성을 경감시키는 효과는 홍삼 투여군에서 더욱 크게 나타났다. ${ }^{86)}$

\section{6. 동물 성장발육에 미치는 효과}

육용추(닭: broiler)의 증체량에 미치는 영향을 홓삼과 백삼 을 사료에 첨가하여 비교한 결과, 8주 후 체중 변화는 대조 군(100)에 비해 백삼은 110 , 홍삼 118 로 증체량에 영향을 미 쳤고, 사료효율(체중 $1 \mathrm{~kg}$ 증가에 필요한 사료량 지수)도 대조 군 100 에 비해 백삼 93 , 홍삼 87로 홍삼이 우수하였다. 또 한 인삼투여 경우 간 조직의 분열증식과 재생성도 좋고 조밀 하여 간기능 촉진효과가 안정되었는데 그 효과는 홍삼 투여 군에서 현저하였다. ${ }^{87,88)}$

\section{7. 방사선 방어 효과}

방사선 피폭 마우스에서 홍삼과 백삼 및 실험적 방사선 방 호제로 알려진 diethyldithiocarbamate(DDC)의 방사선에 대
한 보호효과를 공장음와의 생존 (jejunal crypt survival)과 내재성 비장세포 집락 형성(endogenous spleen colony formation), 그리고 소장 움 세포의 apoptosis 유발(apoptosis of jejunal crypt cells) 정도를 지표로 효과 비교를 하였다. ${ }^{89)}$ 홍삼은 홍삼정분(extract powder Spray-dried)을 사용하고 백삼은 $70 \%$ 에틸알콜 추출물(동결건조품)을 사용하였다. 그 결과 고선량의 방사선 $(12 \mathrm{~Gy})$ 피폭 시 공장단면 주변부의 음와수는 방사선 단독 조사군에 비해 홍삼전투여군 $(50 \mathrm{mg} /$ $\mathrm{kg}$, 조사 전 36 시간과 12 시간, 2 회 복강투여)이 $35 \%$ 증가 하고, 동일 량의 백삼 전투여군에서는 $87.6 \%$ 증가, $\mathrm{DDC}$ $(1000 \mathrm{mg} / \mathrm{kg}$, 조사 전 30 분 1 회 복강투여)는 $103.9 \%$ 의 증 가를 보였다. 중등도 선량 $(6.5 \mathrm{~Gy})$ 조사 시 비장 집락형성은 방사선 단독 조사 대조군에 비해 홍삼 전투여군은 3 배, 조사 후 투여군(방사선 조사 30 분 후 $50 \mathrm{mg} / \mathrm{kg}, 1$ 회 복강 투여) 은 3.7배의 증가를보였다. 백삼 투여군에서는 조사전 투여군 은 7.8배, 조사 후 투여군은 12.7 배의 증가를 보였다. 저선량 $(2 \mathrm{~Gy})$ 의 방사선 조사에 의한 능동적 세포사멸(apoptosis)의 유발은 방사선 단독 조사군에 비해 홍삼 전투여군은 $41.0 \%$ 감 소, 백삼 전투여군에서는 $24.2 \%$ 감소하였고, $\mathrm{DDC}$ 투여군은 $35.1 \%$ 감소하였다. 이상과 같이 홍삼과 백삼의 방사선 보호 효과가 확인되었고, 그 효과 정도는 공장음와의 생존과 내재 성 비장집락 형성에서는 백삼의 호능이, apoptosis 유발 감소 효과는 홍삼이 우수한 것으로 평가되었다.

\section{종합 및 고찰}

인삼은 예로부터 보기(補氣), 자음(㶌除), 익혈(益血), 생진 (牛津) 등 허중(虚症)을 치료하는 이른바 강장(强壯), 강심(强 心), 건위(健胃), 진정(鐄靜)등을 목적으로 사용되어 왔다. 일 반적으로 한의서에 기술된 인삼은 특별한 언급이 없는 한 백 삼을 지칭하며, 홍삼은 약용역사로 보아 한방 후세파(後世派) 가 상용한 것으로 알려지고 있다. ${ }^{2)}$ 이들의 효능은 홍삼과 백 삼 간에 엄격히 구별되는 것은 아니지만, 허(虛)를 보(補)하는 힘은 백삼보다 홍삼이 강한 것으로 인식되어, 한방적으로 허 (虛)의 상태가 매우 심한 경우나, 백삼의 사용으로는 충분한 효과를 얻기 어렵다고 판단될 경우에는 홍삼을 사용하는 것 으로 알려지고 있다. ${ }^{90,91)}$ 그러나 홍삼의 제조역사도 상당히 오래되었는데도 왜 한방처방에 훙삼이 기술되지 않았는지 그 이유는 알 수 없으나, 일반적으로 인삼이 처방된 방제에는 홍 삼을 처방해도 큰 무리는 없다고 여겨지고 있다.

일반적으로 천연물을 소재로 한 생약은 그의 기원과 산지 및 수치법 등에 따라 형태가 다르고 약리활성과 함유성분도 달라서 임상적용 시는 이를 구별하여 사용한다. 
그 중 특히 생약의 수치법에 따른 임상적용의 예로서 지황 (Rehmannia glutinosa)은 생지황, 건지황, 숙지황으로 대별하 는데 한방에서는 각각 약효가 다른 악물로 구별하여 생지황 은 주로 지혈의 목적으로 사용되지만 건지황은 지혈, 청혈, 량혈 등으로 효능이 있어 주로 청혈약으로 열성 질환에 사용하며, 숙지황은 보혈, 강장, 자음 등의 효능이 있어 중요한 보혈약의 하나로 사용된다.) 아울러 전칠삼(Panax notgin$s e n g$ )의 경우도 중의학적으로 생(生)은 지혈과 심혈관 작용을 가지고 있고, 익힌 것은 보혈작용과 빈혈 상태에서 혈액세포 의 증가 목적으로 사용되고 있다.

또한 부자(Aconiti tuber)의 경우 부자 건조근은 맹독성 알 칼로이드(aconitine, hypaconitine, mesacontine 등)가 많이 함유되어 있으나 찐 부자(熟附子)의 경우 맹독성 알칼로이드 함량이 감소되고 저독성인 lipo-alkaloid 성분들이 다수 생성 된다는 것이 밝혀졌다. ${ }^{2)}$ 이처럼 수치(修治)란 한방이론 및 경 험에 근거하여 약제를 천연의 상태에서부터 가공 처리하는 이 른바 한방의 전통적 제약기술을 말한다. 한의학에서 수치(修 治)의 목적은 (1) 독성이나 부작용의 제거 또는 경감 (2) 약성 의 변화 또는 치료효과의 상승 (3) 저장성 양호 (4) 약의 조 제와 제제(製劑)의 편리 (5) 청결 및 복용편의 등으로 알려지 고 있다. ${ }^{9)}$

이러한 수치방법 중 홍삼의 증숙(蒸熟) 가공법은 수증기로 열처리를 하므로 수화제법(水火製法)에 속하며, 바로 이러한 수치법의 차이에 의해 수삼이나 백삼에 비해 홍삼은 저장성 이 양호하고 부작용이나 효력 면에서 차이가 생기게 되는 것 으로 이해되고 있다.

우리나라를 비롯한 일본과 중국의 약전에는 백삼(Ginseng Radix Alba)과 홍삼(Ginseng Radix Rubra)이 별도로 수재 되어있는데 그 적응증을 보면 중국약전에서는 차이점이 발견 되고 있다. 대한약전외 생약규격집 ${ }^{92)}$ 에는 인삼의 주치(主治) (적응증)는 「허탈, 비허완비(脾虛脘病), 구토설사, 허천(虛喘), 소갈(消渴), 열병진상(熱病津傷), 기혈부족으로 인한 망중(忙中), 失眠健忘(실면건망)」으로 되어 있고, 우리나라 기능성 식품 공전에 인삼제품과 홍삼제품의 기능성 내용은 다같이 “원기 회복, 면역력증진, 자양강장에 도움" 으로 되어 있다. 일본의 약국방(藥局方) 해설서 ${ }^{93)}$ 에 기술된 적응증은 (1)허약체질, (2)육 체푀로, (3)병중 병후, (4)위장허약, (5)식욕부진, (6)혈색불량, (7) 냉증 등의 자양강장의 목적으로 되어 있고 홍삼도 이에 준하 는 것으로 되어 있다. 그러나 중국약전 ${ }^{94)}$ 에 제시된 적응증은 차이가 있다. 인삼(백삼)의 경우 (1)體虛忞脫(체허욕탈: 몸이허 약하고 탈진), (2)肢冷脈微(지냉맥미: 팔다리가 냉하고 맥이 약 함), (3)脾虛食少(비허식소: 비장이 약해서 식욕부족) (4)肺虛喘 咳(폐허천해: 폐가 약해서 숨이차고 기침이 남), (5)津傷口渴(진
상구갈: 진액이 말라서 갈증이 있음), (6)内熱消渴(내열소갈: 몸 안에 열이 있어 갈증이 생김), (7)久病虛䇔(구병허리: 오랜 병으 로 몸이 허약하고 마른 상태), (8)忡悸失眠(충계실면양: 놀라서 가슴이두근거리고 불면 상태), (9)陽萎宮冷(양위궁냉:발기부전 과 자궁이 냉함), 그리고 心力衰竭(심력쇠갈:심기능이 약함), 心 原性 休克(심원성 쇼크)로 되어 있다. 홍삼의 경우는 백삼의 (1), (2), (3) 항과 심력쇠갈, 심원성 휴극의 적응증과, 그리고 백삼에 없는 氣不攝血(기불섭혈: 기가 약해서 혈행이 부전), 崩漏下血(붕누하혈: 자궁 출혈)으로 되어 있어 백삼과 홍삼의 적응증이 다소 차이를 보이고 있다. 이러한 적응증은 과학적 연구결과에 근거한 것이라기보다는 주로 한방의학적 효능에 의해 제시된 것으로 여겨진다. 그런데 한의학적 인삼의 성미( 性味)를 일반적으로 온(溫) 또는 미온(微溫)으로 알려지고 있으 나 생(生)으로 쓰면 량(涼)하고 익혀 쓰면 온(溫)하다라고 되어 있다. 이러한 약성(藥性) 차이는 아마도 상기 중국약전에 기술 된 열처리한 홍삼과 생 인삼을 그대로 건조한 백삼간의 적응 증 차이와 관련이 있는 것으로 여겨진다.

그 동안 생약의 수치방법에 따른 과학적 접근에 의해 홍삼 과 백삼의 함유성분에 다소 차이점이 있음이 밝혀지고 있다. 특히 백삼 특유성분 홍삼제조 시 열처리(steaming 처리)와 가 수분해 반응에 의해 화학성분의 구조적 변환이 일어나 홍삼특 유의 암세포증식억제 활성 성분인 ginsenosides- $\mathrm{Rh}_{2},-\mathrm{Rh}_{4}$, $-\mathrm{Rs}_{3},-\mathrm{Rs}_{4},-\mathrm{Rg}_{5}$, 그리고 암세포 전이 억제와및 혈관확장 및 혈소판 응집억제효과 등을 나타내는 ginsenoside- $\mathrm{Rg}_{3}$ 등이 생 성되고, 특히 이들 미량 ginsenosides들은 고온 증삼조건 $\left(120^{\circ} \mathrm{C}\right)$ 에서 그 생성량이 많아진다고 보고 되었다. ${ }^{100)}$ 또한 홍삼제조 시 증삼과정의 열처리뿐만 아니라 홍삼과 백삼의 농 축액 제조 시 추출과정에서 열처리가 가해지면 열에 불안정 한 산성사포닌인 malonyl-ginsenosides은 malonic acid 기가 이탈되어 그에 해당되는 각각의 neutral ginsenosides로 변환 이 일어난다. 아울러 백삼의 농축액 제조 시 추출 및 농축과 정의 열처리 온도와 처리시간에 따라 사포닌의 부분적 가수 분해 반응에 의해 홍삼에서 발견되는 사포닌의 분해산물들이 생성될 수 있다. 그런데, 해외에서 인삼과 인삼농축액의 품질 지포로서 사용되고 있는 진세노사이드는 원래 인삼에 들어 있 는 $\mathrm{G}-\mathrm{Rb}_{1}$ 과 $\mathrm{G}-\mathrm{Rg}_{1}$ 혹은 이를 비롯한 $\mathrm{G}-\mathrm{Rb}_{2}, \mathrm{G}-\mathrm{Rc}, \mathrm{G}-\mathrm{Rd}$, $\mathrm{G}-\mathrm{Re}$ 등 6 종이다. 진세노사이드 함량기준(HPLC-UV 분석법 으로 정량분석)에 대한 예를 들면 미국 약전(U.S. Pharmacopoeia) 에서는 인삼근의 경우 $\mathrm{Rg}_{1} 0.2 \%, \mathrm{Rb}_{1} \quad 0.2 \%$ 이상 으로, 농축액은 상기 6 종의 진세노사이드가 $3.0 \%$ 이상으로 되어 있고, 유럽 약전(European Pharmacopoeia)에서는 G$\mathrm{Rg}_{1}$ 과 $\mathrm{G}-\mathrm{Rb}_{1}$ 의 함량이 $0.4 \%$ 이상으로 되어 있다. ${ }^{102)}$ 중국의 수입의약품으로서 고려홍삼의 품질표준에는 $\mathrm{G}-\mathrm{Rb}_{1}$ 과 $\mathrm{Rg}_{1}$ 및 
$\mathrm{G}-\mathrm{Re}$ 의 함량이 $0.65 \%$ 이상으로 되어 있다. 이러한 인삼의 진세노사이드 함량기준과 관련하여 홍삼의 경우 찌는 온도나 그 시간의 장단, 또는 농축액 제조 시 추출 및 농축 시 열처 리 온도 등에 따라 인삼의 품질 지표 성분으로 이용되고 있 는 ginsenosides를 비롯한 상당한 성분의 변환이 일어날 수 있으므로 이를 고려한 품질관리기준의 설정이 필요할 것으로 사료된다. 그러나 우리나라의 인삼성분의 품질기준을 보면 조 사포닌(n-butanol 추출물) 함량과 $\mathrm{G}-\mathrm{Rg}_{1}$ 과 $\mathrm{G}-\mathrm{Rb}_{1}$ 의 정성적 확인 수준에 머무르고 있다. 즉 현행 인삼산업법의 인삼류(홍 삼과 백삼)의 인삼성분 검사기준의 조사포닌 함량은 본삼류는 $2.0 \%$ 이상, 대미 - 중미류 및 분쇄인삼은 $3.0 \%$ 이상, 세미류 는 $5.0 \%$ 이상, 그리고 묽은 에탄올추출물의 함량은 $18.0 \%$ 이상으로 되어 있다. 또한 기능성식품공전에는 홍삼 및 백삼 분말의 경우 조사포닌 함량이 $20.0 \mathrm{mg} / \mathrm{g}$ 이상으로 되어 있으 나, 인삼(백삼) 농축액의 경우는 조사포닌 함량으로 $80.0 \mathrm{mg} /$ $\mathrm{g}$ 이상, 홍삼농축액은 $70.0 \mathrm{mg} / \mathrm{g}$ 이상으로 되어 있다. 그리 고 인삼(백삼) 및 홍삼제품의 경우 모두 $\mathrm{G}-\mathrm{Rg}_{1}$ 과 $\mathrm{G}-\mathrm{Rb}_{1}$ 이 확인되어야 한다. 이상에서와 같이 해외 인삼 수출을 위해서 는 수출상대국의 품질기준에 적합한 인삼 및 홍삼제품이 제 조되어야한다. 금후 좀더 발전적 품질관리 기준의 설정이 요 망되고 있다.

홍삼 제조과정을 통해 비사포닌계 생리활성물질로 암세포 증식억제 활성을 가진 panaxytriol 등이 생성되고, 그리고 maillard 반응 생성물로 항산화 활성 성분인 maltol 과 당과 아미노산이 결합된 arginyl-fructsyl-glucose 등이 생성된다는 것이 발견되었다.56) 그런데 홍삼이 백삼에 비해 사포닌 성분 을 비롯한 비사포닌 계 성분의 그 함량과 그 조성에 차이를 보이는 것은 홍삼제조과정 중 열처리에 의한 성분변환이나 타 성분과 결합반응으로 원래 수삼 중에 함유되지 않은 새로운 성분이 생성되기도 하고 또한 이에 이용된 일부 성분은 감소 가 일어난다고 보아야 할 것이다. 예를 들면 홍삼제조 시 수 삼 중 가장 많이 함유된 유리아미노산인 arginine이 당과 결 합하여 아미노카보닐 반응생성물(Agr-Fru -Glc)을 만들고, glutamic acid가 pyroglutamic acid로 변환됨으로 현저한 유 리아미노산의 감소가 일어난다. 즉, 홍삼은 백삼에 비해 총 유리아미노산은 현저히 낮지만 약리활성을 물질인 새로운 아 미노산 유도체(Agr-Fru-Glc)나 pyroglutamic acid의 함량은 증가되는 것이다.

또한 항산화 효과 면에서 수삼의 열처리 방법에 있어 수증 기로 찌는 것이 꼻이는 것보다 더 효과적임이 밝혀졌다. ${ }^{85)}$ 그 러나 수삼이나 백삼의 전통적 복용형태인 탕액의 경우, 그 탕 액 중 상기 홍삼특유 성분의 생성에 대해서는 아직 충분히 검토되지 않았다. 더욱이 홍삼과 백삼을 분말형태로 그 대로
섭취할 경우와 홍삼과 백삼을 탕액이나, 그리고 가온 추출한 농축액 형태로 섭취할 경우가 있는데, 그 효과 면에서 어떤 차이가 있는지는 아직 구체적으로 밝혀지지 않고 있다. 수삼 이나 백삼의 경우도 탕액이나 농축액의 제조 과정에서 열처리 가 가해짐으로 열처리에 의한 성분의 변환이 생길 수 있다. 특히 인삼은 전통적으로 탕액으로 섭취하여 왔는데, 수삼이나 백삼, 그리고 홍삼을 약탕기 등에서 끓인 각각의 탕액 성분의 차이에 대한 검토도 필요하며, 이는 인삼의 올바른 섭취방법 을 위한 중요한 정보를 제공하게 될 것으로 사료된다.

최근 홍삼과 백삼 농축액의 사포닌 함량비교에서 조사자에 따라 심한 차이를 보이고 있는데, ${ }^{95)}$ 동일한 원료수삼으로부터 제조된 시료를 사용하지 않았기 때문에 그 함량차이가 과연 가공법에 의한 차이인지, 아니면 원료수삼의 성분 차이에서 비롯된 것인지가 불분명한 점이 많다. 더욱이 백삼의 특유 사 포닌인 malonyl-ginsenoside는 매우 불안정하기 때문에 그 표준품의 확보가 매우 어려워 그 함량분석의 문제점으로 지 적되고 있다. ${ }^{102)}$ 따라서 그 동안의 홍삼과 백삼의 사포닌 함 량비교에서는 백삼 중 malonyl-ginsenosides의 함량 분석은 거의 이루어지지 않았다. 또한 인삼은 원료삼의 재배조건에 따라, 또는 특히 뿌리 부위에 따라 진세노사이드 함량변이가 매우 크다는 점을 고려해야 한다. 금후 동일한 원료수삼으로 부터 제조된 홍삼과 백삼, 그리고 그 추출물에 대한 성분비교 가 이루어져야 할 것이다.

더욱이 해외 인삼시장에서 유통되고 있는 인삼제품 품질평 가에서 인삼의 주요 활성성분으로서 인삼제품의 지표성분으 로 간주되고 있는 진세노시이드 함량 변이가 매우 심하고, 품 질표준화가 되어있지 않으므로 보다 엄격한 품질관리의 필요 성이 강조되고 있다. 인삼의 총 진세노사이드 분석결과들을 보면 주근은 $0.2 \%-2.0 \%$, 세근은 4-9\%의 성분 변이를 보였 다. ${ }^{102)}$ 이러한 변이는 진세노사이드 분석방법과 어떤 종류의 진세노사이드를 정량했느냐에 따라 달라질 수 있으며, 이외에 도 원료삼의 재배환경 즉, 토양, 기후, 지리적 위치, 그리고 재배방법의 차이에 기인될 수 있다. 그러나 이러한 변이는 원 료삼의 생산단계에서 GAP(good agricultural practice)와 제 품제조과정의 GMP(good manufacturing practice)의 도입으 로 최소화되어야 할 것이다.

효능 면에서 지금까지 홍삼과 백삼의 차별성에 대한 in vitro 혹은 in vivo 시험 결과를 종합하면 노화억제효과와 관 련된 항산화 활성을 비롯해서 혈액순환개선 효과, 암발생 억 제력, 감염방어 작용 등의 약리활성이 홍삼이 백삼보다 상대 적으로 우수한 것으로 보고 되었다. 그러나 홍삼과 백삼의 임 상실험에 의한 그 효과의 비교연구는 매우 미흡한 실정이다. 따라서 홍삼과 백삼의 효능비교에 대한 그 동안의 실험적 결 
과가 과연 인체실헙에서 그대로 적용될 것인가에 대해서는 금 후 검토해야 할 과제로 남아 있다. 더욱이 우리나라에서 그 동안 인삼의 효능연구는 대부분 홍삼 위주로 연구되었으며, 백 삼의 분말이나 농축액을 이용한 연구는 매우 제한적이었다. 하 지만 세계적으로 많은 매출액을 올리고 있는 스위스 파마톤사 의 인삼추출물 G115는 백삼으로 만든 제품으로 엄청난 실험 적/임상적 연구가 수행되었음을 간과해서는 안 될 것이다.

또한 최근 인삼의 체내 동태연구를 통해 인삼을 경구투여 할 경우 주요 약효성분인 사포닌 성분은 위액 산성조건이나 장내세균에 의해 대사되어 그 생물전환체가 약효롤 나타내는 것으로 여겨지고 있다. ${ }^{96)}$ 또한 protopanaxadiol types ginsenosides는 경구 투여 후 장내 세균에 의한 최종 대사산물, 20-O- $\beta$-D-glucopyranosyl-20(S)-protopanaxadiol, 일명 compound $\mathrm{K}$ 혹은 compound $\mathrm{M}$ 이라는 것이 보고되었다. ${ }^{97,98)}$ 최근 장내세균인 비피더스균(Bifidobacterium)으로 발효된 홍 삼엑스의 경구투여가 보다 효과적인 허혈 방어 효과를 보였 다는 실험적 증거가 제시되었다. ${ }^{99)}$ 그러나 대부분 in vitro 실험계에서 암세포증식억제 활성을 보인 $\mathrm{G}-\mathrm{Rh}_{2}$ 를 비롯한 구 조가 전환된 홍삼특유 사포닌들이 백삼에서 분리된 구조가 변 환이 되지 않은 원래의 사포닌(intact ginsenosides)의 경구 투여 시 보다 더 효과적인지에 대해서도 좀더 많은 연구가 필요하다.

\section{요 약}

인삼(Panax ginseng C.A. Meyer)은 가공방법에 따라 크 게 백삼과 홍삼으로 분류된다. 가공공정면에서 홍삼은 생인삼 (수삼)을 그대로 건조한 백삼과는 다르게 일정한 온도조건하 에서 수증기로 쪄서 건조 한 인삼으로 두 종류의 인삼 간에 는 열처리 공정에 차이점이 있다.

품질 안정성면에서 홍삼은 열처리과정에서 호소의 불활성 화와 자체 항산화물질의 증가로 저장성이 양호하고, 호화전분 이 되어 끓일 때 내용성분이 잘 우러나오고 소화 흡수도 양 호한 것으로 여격진다.

성분 면에서 홍삼제조 시 열처리(steaming 처리)와 가수분 해 반응에 의해 화학성분의 구조적 변환이 일어나 홍삼특유 의 암세포증식억제 활성 성분인 ginsenosides- $\mathrm{Rh}_{2},-\mathrm{Rh}_{4}$, $-\mathrm{Rs}_{3},-\mathrm{Rs}_{4},-\mathrm{Rg}_{5}$, 암세포 전이 억제 및 혈관확장 효과 등을 나타내는 ginsenoside- $\operatorname{Rg}_{3}$ 등이 생성된다는 것이 밝허졌다. 또한 비사포닌계 생리활성물질로 암세포 증식억제 활성을 가 진 polyacetylenic alcohol의 구조적 변환에 의해 panaxytriol 등이 생성되고, 그리고 maillard 반응 생성물로 항산화 활성 성분인 maltol과 당과 아미노산이 결합된 아미노산 유
도체인 arginyl-fructsyl-glucose 둥이 생성된다.

한편 홍삼과 백삼 및 이들 제품의 수출과 관련하여 각 수 출 대상국의 진세노사이드 수준의 품질관리기준에 대한 충분 한 분석화학적 정보의 확보가 필요하며, 금후 이에 적합한 품 질기준의 설정 보완이 필요할 것이다. 특히 훙삼의 경우 찌는 온도와 시간의 장단에 따라, 또는 그 농축액 제조 시 추출 및 농축 조건(온도와 시간)에 따라 인삼의 품질 지표 성분으 로 이용되고 있는 ginsenosides를 비롯한 상당한 성분의 변 환이 일어날 수 있으므로 이를 고려한 품질관리방법의 고안 이 풜요할 것으로 사료된다.

호능 면에서 홍삼과 백삼의 차별성에 대해서는 in vitro 혹은 in vivo 시험에서 노화억제효과와 관련된 항산화 활성을 비롯해서 혈액순환깨선 호과, 암발생 억제력 등의 약리활성이 홍삼이 백삼보다 상대적으로 우수한 것으로 보고되었다. 아울 러 한방의학에서 일반적으로 허(虛)를 보(補)하는 힘은 홍삼이 강한 것으로 인식되고 있다. 그러나 아직 실제 임상실험에 의 한 비교 평가는 미흡한 실정이며, 특히 경구투여 후 체내 동 태측면에서 그 효과의 차별성에 대한 연구는 거의 이루어지 지 않았다. 금후 홍삼과 백삼의 효과 우열의 측면이 아닌 그 용도와 적응증에 차이가 있는지에 초점을 맞추어 보다 과학 적 평가가 이루어져야 할 것이다.

결론적으로 가능한 동일한 재배조건에서 생산된 원료수삼 으로 제조된 홍삼과 백삼의 원 생약과 그 추출 분획물, 또는 성분을 시료로 하여 화학성분 조성을 비교하고 이와 연계한 실험적 효능연구의 확충과 특히 임상적 효능 비교연구를 통 해 과연 그 적응증에 차이가 있는지에 대한 보다 많은 과학 적 검토가 이루어져야 할 것이다.

\section{감사의 글}

본 논문은 $\mathrm{KT} \& \mathrm{G}$ 중앙연구원에서 지원한 연구비의 일부로 수행되었으며, 이에 깊은 감사를 드립니다. 아울러 농협 고려 인삼창 이광승 박사님의 많은 협조에 감사를 드립니다.

\section{인용문헌}

1. Kitagawa, I. : Chemical studies on the crude drug processing. V. On the constituents of ginseng radix rubra(II): comparison of the constituents of white and red ginseng prepared from the same Panax ginseng root. Yakugaku Zassi. 107, 495-505 (1987).

2. Kitagawa, I. : Chemical investigation of naturally occuring drug materials. Elucidation of scientific basis for traditional medicines and exploitation of new naturally occurring 
drugs. Yakugaku Zasshi. 112, 1-41 (1992).

3. Li, X.G. : Studies on the transforming mechanism of amino acid components in ginseng in the course of ginseng processing. Korean J. Ginseng Sci. 16, 64-67 (1992).

4. Oh, H.L., Lee, S.J., Do, J.H., Kim, S.D. and Hong, S.K. : Physical and chemical characteristics of Panax ginseng starch. Korean J. Ginseng Sci. 5, 114-121 (1981).

5. Kim, H.J. and Jo, J.S. : Physicochemical properties of Korean ginseng root starch. 3. Physical properties of the starch. Korea. J. Ginseng Sci. 8, 135-152 (1984).

6. Matsuda, H. : Study on efficacy of processed ginseng, red ginseng. Natural Medicines. 53, 217-222 (1999).

7. Choi, K.J., Lee, K.S. and Park, J.D. : Quality stability and antioxidant activity of red ginseng stored for long periods. Proc. 5th Int'l Ginseng Symp., Korea Ginseng \& Tabacco Research Institute, Korea, 99-107 (1988).

8. Kim, S.D., Do, J.H. and Oh, H.I. : Antioxidant activity of Panax ginseng browning products. J. Korean Agricultural Chemical Society. 24, 161-166 (1981).

9. Nam, K.Y. : Contemporary Korean Ginseng (Chemical Constituents and Pharmacolgical Activity). Korean Ginseng \& Tobacco Research Institute, Daejeon, Korea, 1-54 (1996).

10. Shoji, J. : Studies on the constituents of ginseng. Natural medicines. 53, 55-59 (1999).

11. 박종대 : 고려인삼20년 연구사, 고려인삼학회 발간, 광일문 화사, p. 69 (1997).

12. Abe, K., Cho, S.I., Kitagawa, I., Nishiyama, N. and Saito, H. : Differential effects of ginsenoside $\mathrm{Rb}_{1}$ and malonyl-ginsenoside $\mathrm{Rb}_{1}$ on long-term potentiation in the dentate gyrus of rats. Brain Research. 649, 7-11 (1994).

13. Kitagawa, I. : Chemical studies on crude drug pression. I. On the constituents of ginseng radix rubra(1). Yakugaku Zasshi. 103, 612-622 (1983).

14. Hikino, H. : Chinese medicinal plants used against hepatitis. Advances in Chinese Medicinal Materials Research, edited by H.M. Chang et al., World Scientific Publ. Co., Singapore, 205-214 (1985).

15. Lee, H.Y., Kim, S.I., Lee, S.K., Chung, H.Y. and Kim, K.W. : Differentiation mechanism of ginsenosides in cultured murine F9 teratocarcinoma stem cells. Proc. 6th Int'l Ginseng Symp., Korea Ginseng Tabacco Research Institute, Korea, 127-131 (1993).

16. Matsuda, H., Namba, K., Fukuda,S., Tani,T. and Kubo M. : Pharmacological study on Panax ginseng C. A. Meyer.III. Effects of red ginseng on experimental disseminated intravascular coagulation. (2) Effects of ginsenosides on blood coagulative and fibrinolytic systems. Chem Pharm Bull. 34, 1153-1157 (1986).

17. Kimura, Y., Okuda, H. and Arichi, S. : Effects of various gin- seng saponins on 5-hydroxytryptamine release and aggregation in humanplatelets. J. Pharma. Pharmacol. 40, 838843 (1988).

18. Saito, Y. : Ginseng and blood vessel wall. Biomedicine \& Therapeutics. 28, 43-46 (1994).

19. Takahashi, E., Kudo, K., Akasaka, Y., Miyate, Y. and Tachikawa, E. : Action of saponin of red ginseng on sympathetic nerve and effects of combination of red ginseng with other herb medicine on cardiac functions. The Ginseng Review. 16, 88-92 (1993).

20. Takahashi, E., Kudo, K., Akasaka, Y., Kakizaki, A., Tachikawa, E. and Kasimoto. : Inhibitory actions of saponin of red ginseng on catecholamine scretions and the effects of combination of red ginseng with other herb medicine on cardiac functions. The Ginseng Review. 18, $87-90$ (1994).

21. Samukawa, K., Yamashita, H., Matsuda, H. and Kubo, M. : Yagaku Zasshi. 115, 241-249 (1995)

22. 松浦廣道: 薬用人參㧍よび近緣植物配當体 の 化學的研究. 藥用人蔘, アメリカ人參. 三七人參の サぱニンの研究 なりび に紅參修治に關する配當体の研究-。博土學位 論文, 廣島大 學醫學部 總合藥學科, Japan (1985).

23. Matsuda, H., Kubo, M. and Mizuno, M. : Pharmacological study on Panax ginseng C. Meyer(VII). Cardiovascular effects of red ginseng and white ginseng. Shoyakugaku Zasshi. 41, 125-134 (1987).

24. Koike, Y., Yoo, Y.C., Matsuzawa, K. and Azuma, I. : Protective effect of oral administration of ginsenoside- $\mathrm{Rb}_{2}$, $20(\mathrm{R})$-and $20(\mathrm{~S})$-ginsenoside- $\mathrm{Rg}_{3}$ on rotavirus infection. The Ginseng Review. 25, 7-9 (1998).

25. Odashima, S., Ota, T., Yamamoto, K.F. and Abe, H. : Induction of phenotypic transformation by plant glycosides in cultured cancer cells. Jpn J Cancer Chemoth. 16, 1483-1489 (1989).

26. Ota, T., Mada, M. and Odashima, S. : Mechanism of action of ginsenoside $\mathrm{Rh}_{2}$ : uptake and metabolism of ginsenoside $\mathrm{Rh}_{2}$ by cultured B16 melanoma cells. J. of Pharmaceutical Sciences. 80, 1141-1146 (1991).

27. Lee, Y.N., Lee, H.Y., Kim, S.I., Kim, Y.S. and Kim, K.Y. : Differention activity of ginsenoside $R h_{1}$ and $R h_{2}$ is mediated by glucocorticoid receptor in F9 stem cells. Proc. '95 Korea Japan Ginseng Symposium. 57-71 (1995).

28. Kim, Y.S., Kim, D.S. and Kim, S.I. : Ginsenoside $\mathrm{Rh}_{2}$ and $\mathrm{Rh}_{3}$ induced differention of HL-60 cells into granulocytes: Modulation of protein kinase $\mathrm{C}$ isforms during differention by ginsenoside $\mathrm{Rh}_{2}$. Int J Biochem Cell Biol. 30, 327-338 (1998).

29. Park, J.A., Lee, K.Y., Oh, Y.I., Kim, K.W. and Kim, S.I. : Activation of caspase- 3 protease via a $\mathrm{Bcl}-2$-insensitive pathway during the process of ginsenoside $\mathrm{Rh}_{2}$-induced apoptosis. 
Cancer Letters. 121, 73-81 (1997).

30. Lee, K.Y., Park, J.A., Chung, E., Lee, H.H., Kim, S.I. and Lee, S.K. : Ginsenoside- $\mathrm{Rh}_{2}$ blocks the cell cycle of SKHEP-1 cells at the G1/S boundary by selectively inducing the protein expression of $\mathrm{p} 27^{\mathrm{Kip} 1}$. Cancer Letters. 110, 193200 (1996).

31. Tode, T., Kikuchi, Y., Kita, T., Hirata, J., Imaizumi, E. and Nagata, I. : Inhibitory effects of oral administration of ginsenoside $\mathrm{Rh}_{2}$ on growth of human ovarian cancers in nude mice. J. Cancer Res. Clin Oncol. 120, 24-26 (1993).

32. Kikuchi, Y., Sasa, H., Kita, T., Hirata, J. and Tode, T., Nagata, I. : Inhibition of human ovarian cancer cell proliferation in vitro by ginsenoside $\mathrm{Rh}_{2}$ and adjuvant effects to cisplatin in vivo. Anticancer Drugs(England). 2, 63-67 (1991).

33. Hasegawa, H., Sung, J.H., Matsumiya, S., Uchiyama, M., Inouge, Y., Kassai, R. and Yamasaki. : Reversal of daunomycin and vinblastine in multdrug-resistant P388 leukemia in vitro through enhanced cytotoxicity by triterpenoids. Planta Medica. 61, 409-413 (1995). Planta Medica 61, 409413 (1995).

34. Park, J.D., Kim, D.S., et al. : Effects of ginseng saponin on modulation of multidrug resistance. Arch Pharm Res. 19(3), 213-218 (1996).

35. Mochizuki, M., Yoo, Y.C., Matsuzawa, K., Sato, K., Saiki, I., Tono-Oka, S., Samukawa, K. and Azuma, I. : Inhibitory effect of tumor metastasis in mice by saponins, ginsenoside$\mathrm{Rb}_{2}, 20(\mathrm{R})$-, and $20(\mathrm{~S})$-ginsenoside- $\mathrm{Rg}_{3}$, of red ginseng. Biol Pharm Bull. 18, 1197-1202 (1995).

36. Shinkai, K., Akedo, H., Mukai, M., Imamura, F., Isoai, A., Kobayashi, M. and Kitagawa, I. : Inhibition of in vitro tumor cel invasion by ginsenoside- $\mathrm{Rg}_{3}$. Jpn. J. Cancer Res. 87, 357-362 (1996).

37. Kim, N.D., Kang, S.Y., Park, J.H. and Schini-Kerth, V.B. : Ginsenoside- $\mathrm{Rg}_{3}$ mediates endothelium-dependent relaxation in response to ginsenosides in rat aorta : role of $\mathrm{K}^{+}$channels. Eur J Pharmacol. 367, $41-49$ (1999).

38. Kim, N.D. : Cardiovascular actions of ginsenosides. Proc. of '99 Korea-Japan Ginseng Symp., 1-15 (1999).

39. Chung, I.D. and Lee, J.S. : Ginsenoside $\mathrm{Rg}_{3}$ increases the ATP-senstive $\mathrm{K}^{+}$channel activity in the smooth muscle of the rabbit coronary artery. Korean J Ginseng Research. 23, 235-238 (1999).

40. Lugnier, C. and Kim, N.D. : Cyclic nucleotide phosphodiestrase as possible targets for ginsenosides. Proc. of the 7th Int.l Symp on Ginseng, the Korean Society of Ginseng, 216223 (1998).

41. Matsuda, H., Kubo, T. and Kubo, M. : Chemical changes of ginsenoside- $\mathrm{Rb}_{1}$ in stomach and improving effects of its product, $20(\mathrm{~S})$-ginsenoside- $\mathrm{Rg}_{3}$ on a peripheral circulation disorder. The Ginseng Review. 28, 12-15 (2000).

42. Kubo, M., Yukawa, H., Inaba, K., Tokunaga, M. and Matsuda, H. : Effect of ginseng on blood rheology using a microchannel method. The Ginseng Review. 29, 9-11 (2001).

43. Samukawa, K., Mattsuda, H. and Kubo, M. : Inhibition of thrombocyte aggregation of red ginseng. -Effects of ginsenosides on pulmonary thromboenbolism-. The Ginseng Review. 14, 57-61 (1992).

44. Lee, S.R., Park, J.H., Choi, K.J. and Kim, N.D. : Inhibitory effects of ginsenoside $\mathrm{Rg}_{3}$ on platelet aggregation and its mechanism of action. Korean J Ginseng Sci. 21, 132-140 (1997).

45. Kim, Y.C., Kim, S.R., Markeloni, G.J. and Oh, T.H. : Ginsenoside $\mathrm{Rb}_{1}$ and $\mathrm{Rg}_{3}$ protect cultured rat cortical cells from glutamat-induced neurodegeneration. $J$ of Neurosience Research. 53, 426-432 (1998).

46. Tachikawa, E., Kudo, K., Nunokawa, M., Kashimoto, T., Takahashi, E. and Kitagawa, S. : Characterization of ginseng saponin ginsenoside- $\mathrm{Rg}_{3}$ inhibition of catecholamine secretion in bovine adrenal chromaffin cells. Biochemical Pharmacology. 62, 943-951 (2001).

47. Kim, S.E., Lee, Y.H., Park, J.H. and Lee, S.K. : Ginsenoside$\mathrm{Rs}_{4}$, a new type of ginseng saponin concurrently induces apoptosis and selectively elevates protein level of p53 and p21 $1^{\mathrm{WAF} 1}$ in human hepatoma SK-HEP-1 cells. European J. of Cancer. 35, 507-511 (1999).

48. Lee, K.Y. and Lee, S.K. : Ginsenoside- $\operatorname{Rg}_{5}$ supresses cyclin E-dependant protein kinase activity via up-regulation of $\mathrm{p} 27^{\mathrm{WAF} 1}$ with concomitant down-regulation of $\mathrm{cdc} 25 \mathrm{~A}$ in SK-HEP-1 cells. Anticancer Res. 17, 1067-1072 (1997).

49. Baek, N.I., Kim, D.S., Lee, Y.H., Park, J.D., Lee, C.B. and Kim, S.I. : Ginsenoside $\mathrm{Rh}_{4}$, a genune dmmarane glycoside from Korean red ginseng. Planta Medica. 62, 86-87 (1996).

50. Hirakura, K., Takagi, H., Morita, M., Nakajima, K., Niitsu, K., Sasaki, H., Maruno, M. and Okada, M. : Cytotoxic activity of acetylenic compounds from Panax ginseng. Natural Medicines. 54, 342-345 (2000).

51. Kobayashi, M., Mahmud, T., Umezome, T., Wang, W., murakami, N. and Kitagawa, I. : The absolute stereostructures of polyacetylenic constituents of ginseng radix rubra. Tetrahdron. 53, 15691-15700 (1997).

52. Katano, M. et al. : Tumor growth inhibitory substance isolated from Panax ginseng C. A. Meyer. Proc. 5th Intl Ginseng Symp. Korea Ginseng \& Tobacco Research Institute, Korea, 33-38 (1988).

53. Matsunaga, H. et al. : Studies on the Panaxytriol of Panax ginseng C. A. Meyer. Isolation, determination and antitumor activity. Chem. Pharm. Bull. 37, 1279-1281 (1992).

54. Lee, S.D., Lee, K.S., Okuda, H. and Hwang, W.I. : Inhibitory 
effect of crude acidic polysaccharide of Korean ginseng on lipolutic action of toxohormone-L from cancerous ascites fluid. Korea J. Ginseng Sci. 14, 10-13 (1990).

55. Okuda, H.: Biological activities of non-saponin compounds isolated from Korean red ginseng. Proc. Intl Ginseng Symp. on Korean Ginseng. The Society for Korean Ginseng. Seoul, Korea, 15-19 (1990).

56. Takaku, T. et al. : Production of arginyl-fructosyl-glucose during processing of red ginseng. J. Traditional Medicines. 13, 118-123 (1996).

57. Park, K. M., Kim, Y.S., Jeong, T.C., Joe, C.H., Shin, H.J., Lee, Y.H., Nam, K.Y. and Park, J.D. : Nitric oxide is involved in the immunomodulating activities of acidic polysaccharide from Panax ginseng. Planta Medica. 67, 122-126 (2001).

58. Park, J.D., Kim, Y.S., Park, K.M., Shin, H.J., Jeong, T.C., Lee, Y.H. and Nam, K.Y. : Biological Activities of water soluble non-saponin constituents from Korean red ginseng.Immunomodulating activities of acidicpolysaccharide. Proc. of '99 Korea-Ginseng Symp. 191-209 (1999).

59. Kim, K.H., Lee, Y.S., Jung, I.S., Park, S.Y., Chung, H.Y., Lee, I.R. and Yun, Y.S. : Acidic polysaccharide from Panax ginseng, Ginsan, induces Th1 cell and macrophage cytokines and generates LAK cells and in synergy with rIL-2. Planta Medica. 64, 110-115 (1998).

60. Nam, K.Y. : Relationship of saponin and non-saponin for the quality of ginseng. The Ginseng Review. 26, 17-25 (1999).

61. 奥田 拓道 : 人蓼の非サポニン分劃とその藥理. The Ginseng Review 臨時號. (No. 26), 78-88 (1999).

62. Takaku, T., Kameda, K., Matsuura, Y., Sekiya, K. and Okuda, H. : Studies on insulin-like substances in Korean red ginseng. Planta Medica. 56, 27-30 (1990).

63. Matsuura, Y., Okuda, H. : Isolation and physiological activities of a new amino acid derrivative from Korean red ginseng. Korean J. Ginseng Sci. 18, 204-211 (1994).

64. Kim, M.W. and Choi, K.J. : Studies on physico-chemical properties of the lipid of red and white ginseng. p. 167-170. In: The Annual Report. Korean Ginseng Research Institute, Korea (1983).

65. Han, B.H. et al. : Chemical and biochemical studies on the antioxidant components. Advances in Chinese Medicinal Materials Research. Chang H. W. et al. eds, World Scientific Co., Philadelphia, 485-498 (1985).

66. Long, Y.C., Ye, F.N., Ye, U. H. and Xing, Q.Y. : Isolation and identification of $\beta-\mathrm{N}-\mathrm{Oxalo}-\mathrm{L}-\alpha, \beta$-diaminopropionic acid and its isomer $\alpha-\mathrm{N}-\mathrm{D}$ N-Oxalo-L- $\alpha, \beta$-Diaminopropionic acid from Panax species. Chinese Chemical Letters. 3, 517520 (1992).

67. Zheng, Y., Matsuura, Y., Hato, T., Murakami, K., Sekiya, K., Kameda, K., Takaku, T. and Okuda, H. : Studies on den- cichine in Korean red ginseng. J. of Medicine and Pharmaceutical Society for WAKAN-YAKU. 8, 39-45 (1991).

68. Kosuge, T., Yokota, M. and Ochiai, A. : Studies on the anihemorrhagic principles in the crude drugs for hemostatics. II. On antiheorrhagic principle in sanchi ginseng radix Yakugaku Zasshi. 101, 629-632 (1981).

69. Kim, N.D. and Kim, I.C. : Studies on hypotensive mechanism of ginseng components. J. Pharmacog. 9, 41-47 (1978).

70. Matsuda, H. : Study on efficacy of processed, red ginseng. Natural medicines. 53, 217-222 (1999).

71. Matsuda, H., Samukawa, K. and Kubo, M. : Remedial effect of red ginseng against peripheral circulatory disturbance. The Ginseng Review. 25, 15-18 (2001).

72. Yun, T.K., Lee, Y.S. and Choi, K.J. : Saponin contents and anticarcinogenic effects of ginseng depending on types and ages in mice. Acta Pharmacological Sinica. 17, 293-298 (1996).

73. Yun, T.K. : Cancer chemopreventive compounds of red ginseng produced from Panax ginseng C.A. Meyer. J. Ginseng Res. 25, 107-111 (2001).

74. Fukushima, Wanibuchi, H. S. and Li, W. : Inhibition by ginseng of colon carcinogenesis in rat. $J$ Korean Med Sci. 16(Suppl): S75-80 (2001).

75. Ichihara, T., Wanabuch, H., Iwai, S., Kaneko, M., Tamano, S., Nishino, H. and Fukuchima, S. : White, but not Red, Ginseng Inhibits Progression of Intestinal Carcinogenesis in Rats. Asian Pac J Cancer Prev. 3, 243-250 (2002).

76. Matsuda, H., Tond, C.N. and Kubo, M. : Pharmacological study on Panax ginseng C. Meyer (XIV). Effects of $70 \%$ Methanolic extract from red ginseng on the cytocidal effect of mitomycin C. Yakugaku Zasshi. 112, 846-855 (1992).

77. Tong, C.N., Matsuda, H. and Kubo, M. : Pharmacological study on Panax ginseng C. Meyer (XV). Effects of $70 \%$ Methanolic extract from red ginseng and white ginseng on the antitumor activity of mitomycin C. Yakugaku Zasshi. 112, 856-865 (1992).

78. Matsunage, H., Katano, M., Saita, T., Yamamoto, H. and Mori, M. : Potentiation of cytotoxicity of mitomycin $\mathrm{C}$ by a polyacetylenic alcohol, panaxytriol. Cancer Chemother Pharmacol. 33, 291-297 (1994).

79. 奧田拓道 : 癌惡液質に 對する紅蓼の作用. 藥用人落 85 (熊谷 朗・奥田拓道編), 共立出版, 東京, 98-107 (1985).

80. Okuda, H. : Inhibitory substances in Korean red ginseng toward toxohormone-L : A toxic substance secreted from tumor cells. The Ginseng Review. 15, $34-37$ (1992).

81. Matsuda, H., Kubo, M., Tani, T., Kitagawa, I. and Mizuno, M. : Pharmacological study on Panax ginseng C. A. Meyer (IX) Protective effect of red ginseng on infection (II). On 
phagocytic activity of mouse reticuloendothelial system. Shoyakugaku Zasshi. 41, 135-141 (1987).

82. Choi, D.H., Choi, S.H., Kim, C.H., Shin, K.H., Min, B.H. and Chun, B.G. : Inhibitory effects of ginseng saponin fractions on dexamethasone-induced thymus apoptosis. Korean J.Ginseng Sci. 21, 160-168 (1997).

83. Lim, C.J., Park, E.H., Rhee, D.K. and Hong, S.K. : Comparative studies on the effects of fresh, white and red ginseng - their effects on the content of several components in rat serum and the production of lipid peroxide in rat liver. Yakhak Hoeiji. 25, 65-73 (1981).

84. Kim, W.Y., Kim, J.M., Han, S.B., Lee, S.K., Kim, N.D. and Park, M.K. : Steaming of ginseng at high tempature enhances biological activity. J. Nat. Prod. 63, 1702-1704 (2000).

85. Park, S.Y., Jung, I., Kang, T.L. and Park, M.K. : Difference between teaming and decocting ginseng. J. Ginseng Res. 25, 37-40 (2001).

86. Shin, M.R. : Studies on the antidotal effect of Panax ginseng. Korean J. Ginseng Sci. 1, 59-78 (1976).

87. Han, D.S. and Bae, D.S. : Comparative study of red ginseng and white ginseng(1). Effect of red and white ginseng on the growth of broiler chicken. Kor. J. Pharmacog. 7, 225-232 (1976).

88. Bae, D.S. and Kim N.S., Han, D.S. : Comparative study of red ginseng and white ginseng(2). Effect of red and white ginseng on the blood picture and liver tissue of broiler chicken. Kor. J. Anim. Sci. 19, 306-311 (1977).

89. Kim, S.H., Lee, H.J., Kim, S.R., Lee, J.H., Jo, S.K., Nah, S.Y., Son, C.H. and Shin, D.H. : Effect of red ginseng, white ginseng and diethyldithiocarbamate in irradiated mice. J. Ginseng Res. 25, 68-73 (2001).

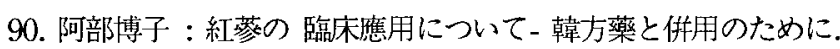
The Ginseng Review. 11, 39-419 (1991).

91. 容忠人：現代醫療に扔ける コウジン末. The Ginseng Review. 6, 3-10 (1988).

92. 대한약전외 생약규격집(주해서) : 지형준, 이상인 편저, 한국 메디칼인덱스사, 518 (1988).
93. 日本藥局方解說書 : 光川書店(東京), D-302-304, D-714 (1991).

94. 中華人民共和國 藥典(1部) : 國家藥典委貣會編, 化學工業出版 社(北京), 6-7, 121 (2000).

95. Ko, S.K., Lee, C.R., Choi, Y. E., Im, B.O., Sung, J.H. and Chung, S.H. : Analysis of ginsenosides of white and red ginseng concentrates. Korean J. Food Sci. Technol. 35, 536-539 (2003).

96. Bae, E.A., Han, M.J., Choo, M.K., Park, S.Y. and Kim, D.H. : Metabolism of $20(\mathrm{~S})$ - and $20(\mathrm{R})$-ginsenoside $\mathrm{Rg}_{3}$ by human intestinal bacteria and its relation to in vitro biological activities. Biol Pharm Bull. 25, 58-63 (2002).

97. Kanaoka, M., Akao, T. and Kobashi, K. : Metabolism of ginseng sapononins, ginsenosides, by human intestinal flora. $J$. Traditional Medicine. 11, 241-245 (1994).

98. Sato, K., Mochizuki, M., Saiki, I., Yoo, Y.C., Samukawa, K. and Azuma, I. : Inhibition of tumor angiogenesis and metastasis by a saponin of Panax ginseng, ginsenoside- $\mathrm{Rb}_{2}$. Biol Pharm Bull. 17, 635-639 (1994).

99. Bae, E.A., Hyun, Y.J., Choo, M.K., Oh, J.K., Ryu, J.H. and Kim, D.H. : Protective effect of fermented red ginseng on a transient focal ischemic rats. Arch Pharm Res. 7, 11361140 (2004).

100. Kwon, S.W., Han, S.B., Park, I.H., Kim, J.M. and Park, M.K. : Liquid chromatographic determination of less polar ginsenosides in processed ginseng. J. Chromatogr. A. 921, 335339 (2001).

101. Ma, T.C. and Yu, Q.H. : Effect of 20(s)-ginsenoside-Rg ${ }_{2}$ and cyproheptadine on two way active avoidance learning and memory in rats. Azgencmittelforschung. 43, 1049-1052 (1993).

102. Fuzzati, N. : Analysis methods of ginsenosides. J. Chromatogr. B. 812, 119-133 (2004).

103. Shin, H.J., Kim, Y.S., Kwak, Y.S., Song, Y.B., Kim, Y.S. and Park, J.D. : Enhancement of antitumor effects of paclitaxel (taxol) in combination with red ginseng acidic polysaccharide (RGAP). Planta Med. 70, 1033-1038 (2004). 